\title{
Metal Supported Solid Oxide Fuel Cell Using Proton Conducting Electrolyte for Direct Ammonia Utilization
}

\author{
Edwin Vega Hiraldo \\ ev0019@mix.wvu.edu
}

Follow this and additional works at: https://researchrepository.wvu.edu/etd

Part of the Ceramic Materials Commons, and the Other Materials Science and Engineering Commons

\section{Recommended Citation}

Vega Hiraldo, Edwin, "Metal Supported Solid Oxide Fuel Cell Using Proton Conducting Electrolyte for Direct Ammonia Utilization" (2021). Graduate Theses, Dissertations, and Problem Reports. 8286.

https://researchrepository.wvu.edu/etd/8286

This Thesis is protected by copyright and/or related rights. It has been brought to you by the The Research Repository @ WVU with permission from the rights-holder(s). You are free to use this Thesis in any way that is permitted by the copyright and related rights legislation that applies to your use. For other uses you must obtain permission from the rights-holder(s) directly, unless additional rights are indicated by a Creative Commons license in the record and/ or on the work itself. This Thesis has been accepted for inclusion in WVU Graduate Theses, Dissertations, and Problem Reports collection by an authorized administrator of The Research Repository @ WVU. For more information, please contact researchrepository@mail.wvu.edu. 


\title{
Metal Supported Solid Oxide Fuel Cell Using Proton Conducting Electrolyte for Direct Ammonia Utilization
}

\author{
Edwin Vega Hiraldo
}

Thesis submitted to

Benjamin M. Statler College of Engineering and Mineral Resources at West Virginia University in partial fulfillment of the requirements

for the degree of

Master of Science

In

Material Science and Engineering

Xingbo Liu, Ph.D., Chairperson

Wenyuan Li, Ph.D., Advisor

Ever Barbero, Ph.D.

Department of Mechanical and Aerospace Engineering

Morgantown, West Virginia

2021

Keywords: Metal support SOFCs, Ammonia feeding, Infiltration Copyright 2021 Edwin Vega Hiraldo 


\section{Abstract \\ Metal Supported Solid Oxide Fuel Cell Using Proton Conducting Electrolyte for Direct Ammonia Utilization \\ Edwin Vega Hiraldo}

Transportation represents about $27 \%$ of global warming greenhouse gas emissions nowadays. To reduce these emissions, fuel cell electric vehicles have been poised to be a new trend to provide zero-emission transportation. Among them, solid oxide fuel cells (SOFCs) offer efficient, clean energy, especially when powered by carbon-free fuel, such as ammonia. To enable onboard ammonia-fed SOFCs, a metal-supported, proton-conducting SOFC is investigated in this study. The metal support would provide physical robustness for thermal shock during vehicles' quick start-up and shutdown, reduce internal temperature gradients due to the greater thermal conductivity of the metal, and enable conventional metal joining for easy manufacturing. The proton-conducting electrolyte avoids the mixing of $\mathrm{O}$ and $\mathrm{N}$, only leads $\mathrm{H}$ to the air side for electrochemical reaction.

This study is dedicated to overcoming the barriers in the fabrication of metalsupported H-SOFCs and innovating electrolyte and cathode materials for cuttingedge performance. Different metals, pore forms and processing procedures have been employed to achieve a robust, well-functioning metal-ceramic bilayer assembly. The composition of the $\mathrm{Ba}(\mathrm{ZrCeYYb}) \mathrm{O}_{3}$-based perovskite protonconducting electrolyte has been particularly tuned to yield a high ionic conductivity at the presence of $\mathrm{Ba}$ evaporation and diffusion to metal support during hightemperature treatment. $\mathrm{A} \mathrm{H}^{+}, \mathrm{e}, \mathrm{O}^{2-}$ triple conducting cathode is modified with surface infiltration to achieve excellent electrochemical catalytic activity at intermediate temperature. In the end, a Ni//BZCYYb//PNO metal-supported cell is successfully obtained. A peak powder density of $231 \mathrm{~mW} / \mathrm{cm}^{2}$ is achieved at $650^{\circ} \mathrm{C}$ using ammonia directly, one of the best performances among the reported in the literature. These results bring us closer to the goal of more accessible and affordable technology for fuel cell-powered transportation. 


\section{Acknowledgments}

I would like to express my respect and appreciation to my supervisor Dr. Xingbo Liu and Dr. Wenyuan Li, for providing me with the opportunity to pursue my master's degree. I am thankful for their understanding, patience, and encouragement during my research as well to Dr. Ever Barbero for his support during my admission for my master's.

I also thank my group members, Bo Guan, Hanchen Tian, and Yi Wang for their assistance and experimental discussion.

Special thanks to Victoria Sánchez Gúzman for her support, understanding, and encouragement during my graduate study and daily life as well to my family. 


\section{Table of Contents}

Acknowledgments ............................................................................................................. iii

List of Figures................................................................................................................

List of Tables ................................................................................................. vi

Chapter 1: Introduction and Research Objectives ................................................... 1

1.1- Proton-Conducting Principles ..................................................................... 3

1.2- Metal-supported SOFC ………………………………………….... 4

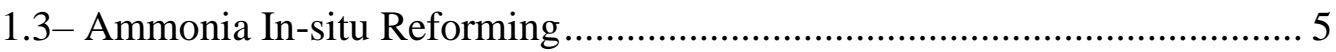

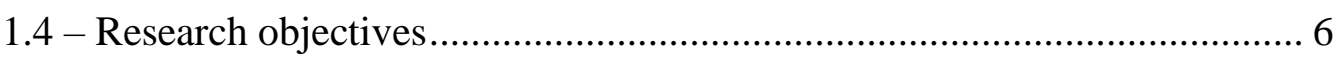

Chapter 2: Experimental methods .......................................................... 7

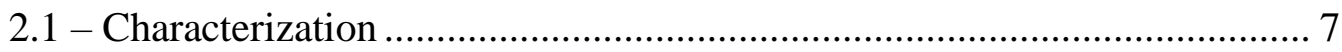

2.2 - Fabrication of dense electrolyte (BZCYYb) ........................................... 7

2.3 - Fabrication of triple-conducting cathode (PNO-BZCYYb) ……………... 8

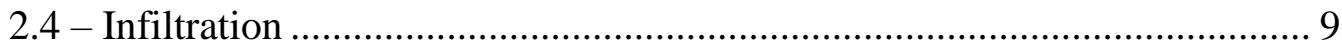

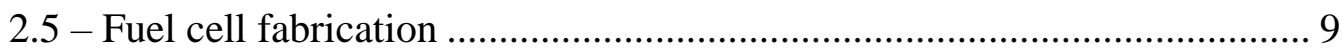

Chapter 3: Metal support fabrication......................................................................... 10

3.1 - Stainless steel metal support .............................................................. 10

3.1.1 - Pore former selection ...................................................................... 10

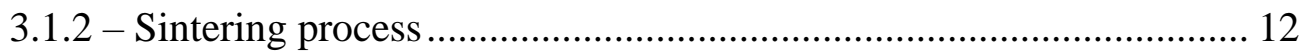

3.2 - Nickel oxide metal support ................................................................. 13

3.2.1 - Shrinkage and Pore formation …………………............................ 13

3.2.2 - Sintering and Support reduction .................................................... 14

3.3 - Chapter Summary …………………………………………………...... 18

Chapter 4: Electrolyte enhancement and Cathode surface modification by infiltration method ............................................................................. 20

4.1 - Effect of non-stoichiometric $\mathrm{B}_{1+\mathrm{x}} \mathrm{ZCYYb}$.......................................... 20

4.2 - Surface modification by Infiltration method........................................... 22

4.2.1 - Infiltration/ impregnation ................................................................. 22

4.2.2 - Infiltration Process ....................................................................... 23

4.2.3 - Precursor selection and characterization........................................... 24

4.3 - Steam interference in ORR ........................................................... 28

4.4 - Chapter Summary ……………………………………………….... 29

Chapter 5: Ammonia direct feeding........................................................................... 30

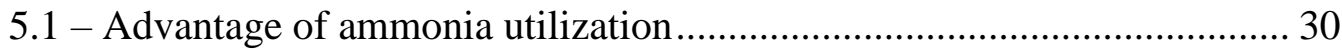


5.2 - Fuel cell measurements ................................................................... 30

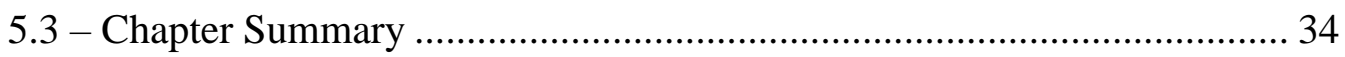

Chapter 6: Conclusion ...................................................................................... 35

References 37

\section{List of Figures}

Figure 1: (a) $\mathrm{O}$, e-conductive cathode limits the reaction to 3PB only, (b) triple conducting PNO expands the reaction to the entire surface of PNO.... 3

Figure 2: $\mathrm{ABO}_{3}$ perovskite structure............................................................ 4

Figure 3: Sketch of the Meta-supported SOFC.................................................. 5

Figure 4: Iron-based Stainless-steel supported cell structure using NaAlO2 as pore former. (a) After sintering. (b) After cell wash.

Figure 5: Stainless steel oxidation a couple of days after sintered using different pore formers: (a) $\mathrm{NaCl}$ and (b) $\mathrm{NaAlO}_{2}$. 12

Figure 6: Stainless steel support shrinkage after sintering using different amount of starch as pore former................................................................ 13

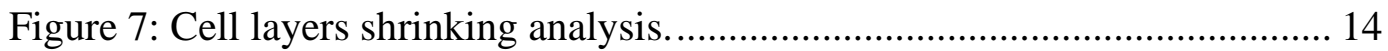

Figure 8: Fuel cell final shape after sintering. Nickel support cell without BZCYYb (left sample), Nickel supported cell with 5wt\% BZCYYb (right sample).

Figure 9: SEM cross-section image of Metal support (MS) and Anode function layer (AFL) interface. (a) Before reduction and (b) After reduction. .. 17

Figure 10: Cell holder.

Figure 11: XRD patterns of $\mathrm{B}_{1+\mathrm{x}} \mathrm{ZCYYb}(\mathrm{x}=0,0.05,0.1)$ after sintering at $1320^{\circ} \mathrm{C}$ for $4 \mathrm{~h}$. 20

Figure 12: Electrochemical impedance spectroscopy (EIS) of fuel cell with different A-site concentration in the electrolyte layer at $650{ }^{\circ} \mathrm{C} \ldots \ldots . .21$

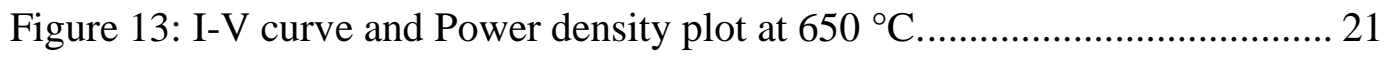

Figure 14: SEM image of PNO-BZCYYb cross section infiltrated with CoO..... 25

Figure 15: Polarization resistance behavior of infiltrated PNO-BZCYYb electrode in $3 \%$ steam at different temperatures. (a) $600{ }^{\circ} \mathrm{C}$, (b) $650{ }^{\circ} \mathrm{C}$, and (c) $700{ }^{\circ} \mathrm{C}$. 
Figure 16: EIS measurement for Co infiltrated PNO-BZCYYb symmetric cell in dry air, $5 \%, 10 \%, 15 \%$ and $20 \%$ steam at 650 C.......................... 28

\section{List of Tables}

Table 1: Pore former advantages and disadvantages. .................................. 10

Table 2: Infiltrated cell identification. ........................................................ 24 


\section{Chapter 1: Introduction and Research Objectives}

A proton-conducting SOFC (H-SOFC) leads to higher performance than an oxygen-conducting SOFC (O-SOFC) at lower temperatures when fed with $\mathrm{NH}_{3}$. The equilibrium potential of the HSOFC is much greater than that of the O-SOFC when various electrolytes with different fuel utilization are used in ammonia-fed SOFCs. H-SOFC efficiency becomes greater than O-SOFC's efficiency due to undiluted fuel in the H-SOFC. The difference in efficiency between them becomes larger as the fuel utilization increases. At a fuel utilization of about $80-90 \%$, the ammonia-fed H-SOFC is about $10 \%$ more efficient than that of the H-SOFC [1]. Thermodynamic analysis indicates that the peak power density of ammonia-fed SOFCs based on proton-conducting electrolytes is $20-30 \%$ higher than that of SOFCs based on $\mathrm{O}_{2}$ - conducting electrolytes, which is mainly attributed to the higher concentration of hydrogen at the anode in all cases [2]. Challenges for hightemperature ammonia-fed SOFCs include performance durability and cost of fabricating the cells. The operating temperature strongly affects the performance of the fuel cell. The small activation energy of $\mathrm{H}$-conducting electrolyte $(0.6 \mathrm{eV}$ vs $0.9 \mathrm{eV}$ for $\mathrm{O}_{2}$-conducting $\mathrm{YSZ}$ ) allows the system to operate at intermediate temperature $\left(550-700^{\circ} \mathrm{C}\right)$ while still showing high performance. At $650^{\circ} \mathrm{C}$, protonconductor BZCY shows a conductivity of $0.02 \mathrm{~S} / \mathrm{cm}$ vs. $0.006 \mathrm{~S} / \mathrm{cm}$ for YSZ. This high proton conductivity diminishes the ohm resistance associated with the dense electrolyte layer and sustains high electrode/electrolyte interface reaction kinetics. Operating at this intermediate temperature relaxes the demanding requirements for thermal management, sealing, interconnection, and electrode stability, reducing system cost and long-term stability. An intermediate temperature H-SOFC adapts more easily to quick start-up and shutdown. Traditional O-SOFCs, run at 800$900^{\circ} \mathrm{C}$, pose bigger challenges to the fuel cell's structural integrity upon steep temperature ramps.

While the electrolyte is important, the anode's low conversion rates of $\mathrm{NH}_{3}$ to $\mathrm{H}_{2}$ is the current bottleneck for H-SOFCs. The ammonia undergoes a two-step reaction at the anode: $\mathrm{NH}_{3}$ decomposes into $\mathrm{H}$ and $\mathrm{N}$, and then $\mathrm{H}$ is electrochemically oxidized to $\mathrm{H}_{2} \mathrm{O}$. The anode materials need to be active for both catalytic ammonia 
decomposition and electrochemical hydrogen oxidation. To date, systematic investigations on the effects of active metals $(\mathrm{Ru}, \mathrm{Rh}, \mathrm{Pt}, \mathrm{Pd}, \mathrm{Ni}, \mathrm{Fe})$ supported on carbon nano-tubes for $\mathrm{NH}_{3}$ conversion have been conducted [3]. The activity of these catalysts can be ordered as $\mathrm{Ru}>\mathrm{Rh} \approx \mathrm{Ni}>\mathrm{Pt} \approx \mathrm{Pd}>\mathrm{Fe}$. Though $\mathrm{Ru}$-based catalysts show the highest activity for ammonia decomposition, their high cost is an obstacle. Among non-noble metals, Ni shows the best performance. Ni-ionic conductor cermet has been verified as excellent anode material due to its good chemical compatibility, high catalytic activity towards fuel oxidation, and low cost. The cermet not only functions as an ionic conductor, providing ionic current in the composite anode, the cermet also acts as a catalyst support for the $\mathrm{Ni}$ and plays a critical role in ammonia decomposition. The ammonia decomposition activity of Ni catalysts supported on various oxides has been investigated [4-6]. Rare-earth oxides are effective supports, with $\mathrm{Y}_{2} \mathrm{O}_{3}$ notably enhancing activity [5]. Fixed bed reactions measurements showed a high ammonia conversion rate of $70-80 \%$, which is consistent with the high conversion rate predicted by thermodynamics. However, a porous anode sintered at high temperatures showed low activity. The low conversion may be due to short residence time caused by the anode's limited thickness and its possibly compromised specific surface area due to hightemperature sintering during fuel cell fabrication. Therefore, we propose a mechanism-guided process for developing an $\mathrm{NH}_{3}$-fed $\mathrm{H}-\mathrm{SOFC}$ anode based on a proton-conducting system. One of our efforts will focus on a $\sim 10 \mu \mathrm{m}$ thick anode functional layer to overcome the $\mathrm{NH}_{3}$ conversion bottleneck. Through in-situ electrochemical catalysis, hydrogen could be provided as $\mathrm{H}+$. This would eliminate the interference of $\mathrm{P}_{\mathrm{H} 2}$ to the ammonia conversion rate and bypass several intermediate reactions involved in the ionization of $\mathrm{H}_{2}$, enhancing both the ammonia conversion rate and fuel oxidation kinetics.

To complement the anode, a novel cathode is needed to reduce polarization resistance at intermediate temperature operation. the triple conducting layerstructure material, $\mathrm{Pr}_{2} \mathrm{NiO}_{4}$, has been verified for its proton conductivity and excellent electrode performance in H-SOFCs [7]. Employing PNO as the cathode for the proposed $\mathrm{NH}_{3}$-fed SOFC will ensure high performance at intermediate temperatures and stable long-term operation. Figure 1 shows the reaction pathways 
for current cathodes (a) and the proposed cathode (b) which offers significant advantages for reaction sites.

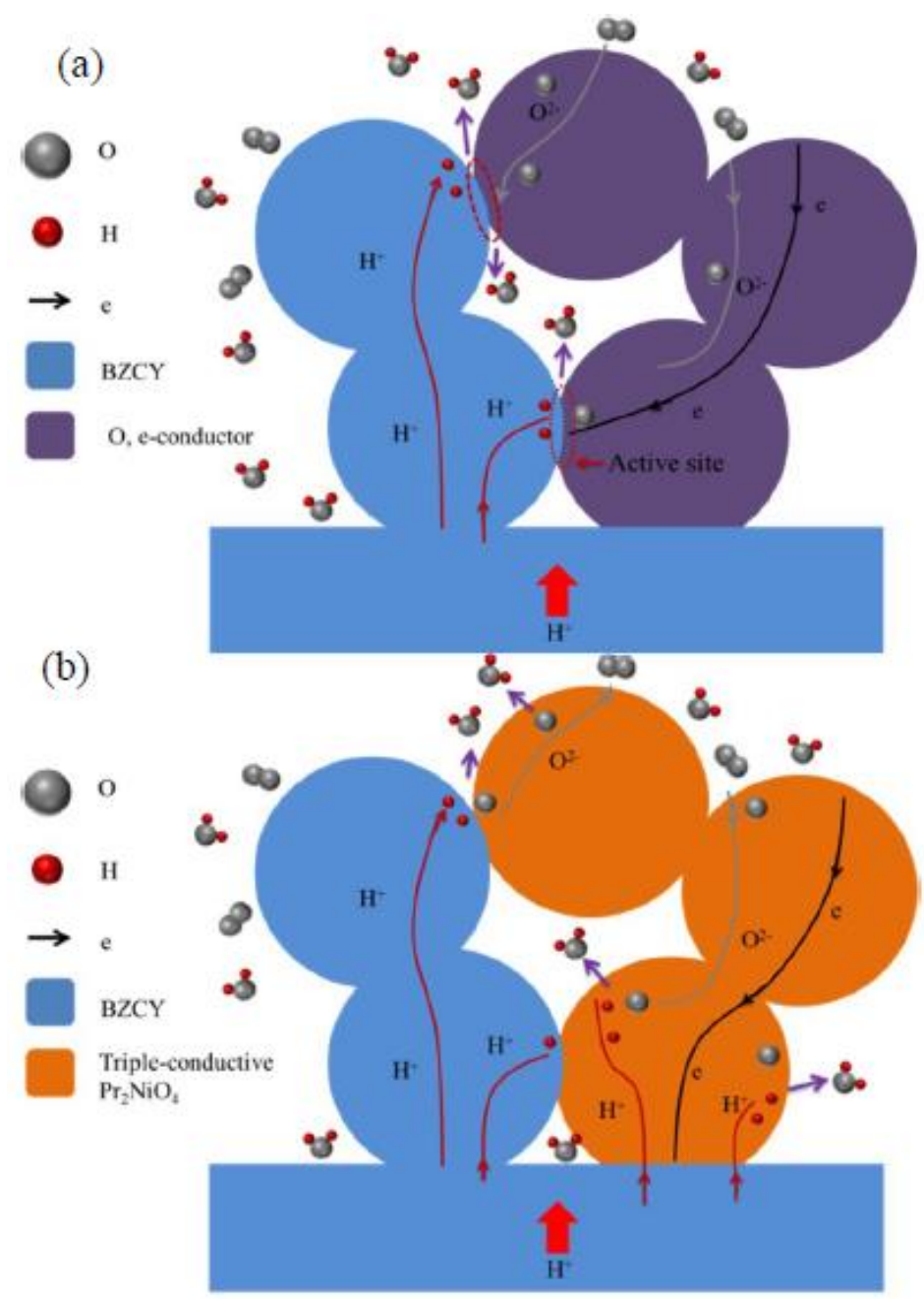

Figure 1: (a) $\mathrm{O}$, e-conductive cathode limits the reaction to 3PB only, (b) triple conducting PNO expands the reaction to the entire surface of PNO.

\section{1- Proton-Conducting Principles}

Perovskite oxides offer in almost all respects a wide variety of properties because of the structure's ability to host varying cations, substitutions, nonstoichiometry, and defects of any kind [8]. This $\mathrm{ABO}_{3}$ structure is illustrated in Figure 2 . The cation in the $\mathrm{B}$ site with a valence of +4 is usually a transition metal or a rare-earth metal. The A site is larger than the B site elements and exhibits a +2 valence with a coordination number of 12 . 


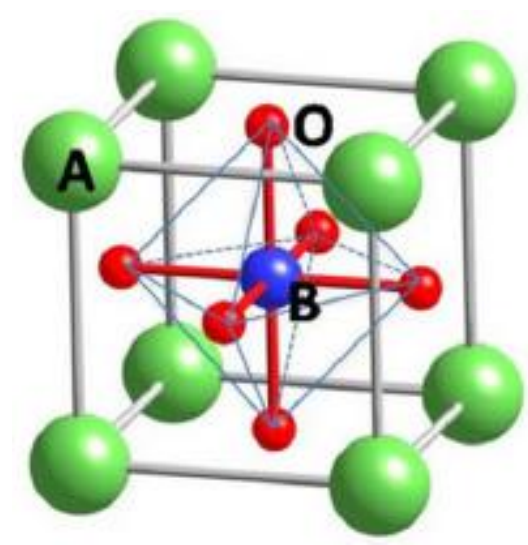

Figure 2: $\mathrm{ABO}_{3}$ perovskite structure.

Proton conduction, resulting from oxide ability to dissolve protons from water vapor or hydrogen [8]. Upon exposure to water, oxygen vacancies in the perovskite lattice can be filled by $\mathrm{H}_{2} \mathrm{O}$, resulting in the introduction of $\mathrm{H}^{+}$ions into the material. While the protons introduced by this manner are closely associated with oxygen ions, the binding energy is not too large, and at intermediated temperatures the protons are able to migrate fairly easily from oxygen ion to the next by lattice diffusion [9]. The Kroger-Vink notation for this protonic conductor is written as

$$
\mathrm{H}_{2} \mathrm{O}+\mathrm{V}_{o}^{*}+\mathrm{O}_{o}^{x} \rightarrow 2(\mathrm{OH})_{o}^{\cdot}
$$

\section{2- Metal-supported SOFC}

Metal-supported SOFCs (MS-SOFCs) are referred to as third-generation SOFCs. In this design, the mechanical and the electrochemical reaction functions of the anode are separated by the support thickness $(\sim 1 \mathrm{~mm})$ which provides mechanical strength, electrical connectivity, and improved heat distribution, while the thin functional anode $(\sim 10 \mu \mathrm{m})$ ensures electrocatalytic function. The advantages of this technology are lower materials cost and easier cell handling and assembling. By using alloy support, the cell is expected to show improved mechanical strength, tolerance to redox cycles, and the ability to withstand repeated and rapid thermal cycles. A SOFC with these features lends itself admirably to the transportation sector where physical robustness is needed. In addition, metal- 
supported H-SOFCs can be operated at lower temperatures down to $600-650 \mathrm{oC}$ due to the high ionic conductivity of the $\mathrm{H}$-conducting electrolyte. Because water is generated at the cathode side of the cell, and because the metal support is on the anode side of the cell, long-term corrosion of the metal support due to hightemperature steam can be alleviated. Porous metal supports must meet the following requirements: high mechanical strength, low corrosion rate, and low resistivity as an oxide scale forms under oxidizing conditions during operation. Its thermal expansion coefficient (TEC) must reasonably match the TEC of other cell elements.

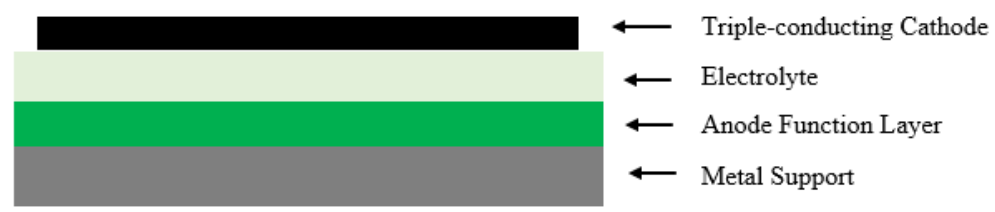

Figure 3: Sketch of the Meta-supported SOFC.

\section{3- Ammonia In-situ Reforming}

To improve the performance of an H-SOFC, it is important to understand the mechanism of ammonia utilization over the anode. Currently, scientist use a twostep process mechanism to describe how a proton conductor serves as an electrolyte following the equations bellow:

$$
\begin{aligned}
& \mathrm{NH}_{3}(\mathrm{~g}) \rightleftharpoons \mathrm{N}_{2}(\mathrm{~g})+3 \mathrm{H}_{2}(\mathrm{~g}) \\
& \mathrm{H}_{2}(\mathrm{~g}) \rightleftharpoons 2 \mathrm{H}^{+}(\mathrm{g})+2 \mathrm{e}- \\
& 2 \mathrm{NH}_{3}(\mathrm{~g}) \rightleftharpoons \mathrm{N}_{2}(\mathrm{~g})+6 \mathrm{H}^{+}
\end{aligned}
$$

To improve ammonia utilization and cell performance, previous studies focused on modifying the $\mathrm{H}_{2}$ formation by $\mathrm{NH}_{3}$ decomposition on the catalyst, as in Eq.1.2, to provide more $\mathrm{H}_{2}$ demanded by electrochemical reaction occurring at the active site. Although the equilibrium conversion of ammonia is $>99 \%$ above $400{ }^{\circ} \mathrm{C}$, a considerable ratio of unused $\mathrm{NH}_{3}$ exhausts, especially at lower temperatures. Fixed bed reactor measurements show that for O-SOFCs, only $\sim 60 \%$ ammonia is 
decomposed at the Ni/YSZ catalyst at $600{ }^{\circ} \mathrm{C}$ [10]. Worse yet, at the typical Operating condition of $600{ }^{\circ} \mathrm{C}$, flow rate $100 \mathrm{~mL} / \mathrm{min}, \mathrm{NH}_{3}$ decomposition in a $\mathrm{Ni} / \mathrm{YSZ}$ anode is $<5 \%$ [10]. As $\mathrm{H}_{2}$ concentration in the mixture increases, this rate drops less than $1 \%$.

The remaining ammonia which has not catalytically decomposed on the catalyst and diffused onto an electrochemical reaction site will tend to crack into N2 and $\mathrm{H}+$ as in Eq. 3, by electrochemical activation, given sufficient polarization overpotential. This reaction rate increases exponentially by applying 0verpotential. This means that this $\mathrm{NH} 3$ reaction pathway contributes more significantly at larger current density. Due to the anode's proton-conducting nature, an H-SOFC will have better catalytic performance for NH3 decomposition than an O-SOFC. The anode polarization resistance from an EIS test under direct current bias with threeelectrodes can be used to discern this mechanism. This mechanism may bring forth a new perspective to improve the performance and efficiency of energy conversion as opposed to the conventional approaches in previous work.

\section{4 - Research objectives}

In this study, the main effort is on the fabrication of a metal supported solid oxide fuel cell and its characterization using ammonia as fuel directly from the fuel source to the cell. Consequently, the modification and improvement of protonconducting BZCYYb electrolyte by changing the A-site stoichiometry, and tripleconducting PNO cathode through infiltration technique are studied as well. 


\section{Chapter 2: Experimental methods}

\section{1 - Characterization}

X-ray diffraction (XRD, PANalytical X'pert $\mathrm{PRO}, \mathrm{Cu} \mathrm{K} \alpha$ radiation) was performed to target the sintering temperature that provides single perovskite and Ruddlesden-Popper single phase for BZCYYb electrolyte and PNO cathode, respectively.

The electrochemical performance for the symmetrical cells is measure by electrochemical impedance spectroscopy (EIS) which was carried out in a temperature-programed tube furnace using Metrohm Autolab test station (AUT85484) at frequencies from $1 \mathrm{MHz}$ to $0.1 \mathrm{~Hz}$. For PNO-BZCYYb cathode performance before and after infiltration, EIS characterization was conducted on symmetric cells under 3 different steam concentrations. The EIS for a single fuel cell a 4-probe configuration was used. For all the samples measured, silver paste and wires were used as current collectors.

Cells cross-sectional imaging was also performed using a scanning electron microscope (SEM, Hitachi S-4700) to observe the cell microstructure.

\section{2 - Fabrication of dense electrolyte (BZCYYb)}

BZCYYb $\left(\mathrm{BaZr}_{0.1} \mathrm{Ce}_{0.7} \mathrm{Y}_{0.1} \mathrm{Yb}_{0.1} \mathrm{O}_{3}\right)$ powder was prepared as the electrolyte material. $\mathrm{Ba}\left(\mathrm{NO}_{3}\right)_{2}, \mathrm{Zr}\left(\mathrm{NO}_{3}\right)_{2} \cdot 6 \mathrm{H}_{2} \mathrm{O}, \mathrm{Ce}\left(\mathrm{NO}_{3}\right) \cdot 6 \mathrm{H}_{2} \mathrm{O}, \mathrm{Y}\left(\mathrm{NO}_{3}\right) \cdot 6 \mathrm{H}_{2} \mathrm{O}$, and $\mathrm{Yb}\left(\mathrm{NO}_{3}\right.$ )$_{3} \cdot 5 \mathrm{H}_{2} \mathrm{O}$ powders, were the starting salts for the electrolyte synthesis. Following the stoichiometric, the powders were dissolved in distilled water. Citric acid and Ethylenediaminetetraacetic (EDTA) were added in the metal ion solution as chelating agents in a (Metal cation:Citric acid:EDTA) 1:1.25:1 molar ratio. Ammonia solution was added to reach a $\mathrm{pH}$ value between 8 10. The solution was

stirred and heated on a heating plate (set to $350^{\circ} \mathrm{C}$ ) until a gel solution was formed. The solution was then moved to an oven overnight to continue the auto-combustion. The powder was fired at $600^{\circ} \mathrm{C}$ for $24 \mathrm{~h}$ in a box furnace to burn out any organic 
residuals. After burning the powder, it is calcined at $1100^{\circ} \mathrm{C}$ for $5 \mathrm{~h}$ in air to obtain a perovskite structure. 3 wt. $\%$ of $\mathrm{Zn}\left(\mathrm{NO}_{3}\right)_{2} \cdot 6 \mathrm{H}_{2} \mathrm{O}$ was added to the electrolyte powder as a sintering aid, which allows the electrolyte densification at lower temperatures.

For symmetrical cells, the electrolyte powder is then ball-milled for $24 \mathrm{~h}$ and dry. 3 wt.\% PVB binder was added to the powder, followed by dry pressing to disk shape $(\Phi 16 \mathrm{~mm})$ in a (Carver benchtop auto pellet press) hydraulic press at 300 $\mathrm{MPa}$. The pellets were then sintered at $1300^{\circ} \mathrm{C}$ for $4 \mathrm{~h}$ for densification. As for the metal-supported cell, VEH is used to make the slurry instead of PVB and spincoated on top of the anode function layer (AFL).

\section{3 - Fabrication of triple-conducting cathode (PNO-BZCYYb)}

$\mathrm{Pr}_{2} \mathrm{NiO}_{4-\delta}(\mathrm{PNO})$ was selected as the cathode electrode. PNO precursor was prepared by sol-gel method. Stoichiometric metal acetates together with citric acid will be dissolved into distilled water separately. EDTA as complexing agent will be dissolved into diluted ammonia water (at a mole ratio of metal cation: citric acid: EDTA of 1:1.25:1). The solutions will be mixed together. The $\mathrm{pH}$ is adjusted to 8 , then held at $80^{\circ} \mathrm{C}$ and stirred until gelation. The powder was then fired at $600^{\circ} \mathrm{C}$ for $24 \mathrm{~h}$ to burn all the organic residuals. The powder is then calcined at $1000^{\circ} \mathrm{C}$ for 4 $\mathrm{h}$ to form a Ruddlesden-Popper structure. Follow the calcination, the powders are then ground to fine powders using zirconia balls.

PNO and BZCYYb powders were mixed in a 6:4 weight ratio. This provides a stronger structure for the electrode bulk and better adherence to the electrolyte. Ink vehicle (Fuel cell materials co.) is added to the composite powder to make the slurry. The mixture was ground in a mortar manually until a homogeneous slurry was obtained. The slurry was applied to both sides of the BZCYYb electrolyte pellet using hand-brushing, then fired at $1100^{\circ} \mathrm{C}$ for $3 \mathrm{hr}$. in air to burn all the organic components from the electrode. 


\section{4 - Infiltration}

Using an aqueous solution, different candidates were selected as the precursor. The solution has a concentration of $0.2 \mathrm{~mol} / \mathrm{L}$ mixed with citric acid in a weight ratio 1:1 in DI water to provide better impregnation of the solution through the electrode pores.

In order to achieve a good deposition of the precursors, after each infiltration, the sample was vacuumed to remove the air inside the electrode bulk, securing that the precursor penetrated all the way into the backbone. This cycle was repeated several times followed by firing the samples at $850{ }^{\circ} \mathrm{C}$ for $3 \mathrm{hr}$. to burn the organic materials and nitrate.

\section{5 - Fuel cell fabrication}

Nickel oxide powder was mixed with $5 \mathrm{wt} \% \mathrm{BZCYYb}$ to make the cell supporting layer. Starch from rice as used as pore former in a support-material to pore former ratio of 10:1. $3 \mathrm{wt} \% \mathrm{PVB}$ was added to the powders as the binder. The resulting powder was then dry pressed into a disc mold to create a $16 \mathrm{~mm}$ in diameter pellet. Ni-BZCYYB anode function layer and BZCYYb electrolyte were spin-coated on the support. After each layer, the cell was put in an oven to dry prior to applying the next coat followed by a final press at $300 \mathrm{MPa}$ and sintered at 1300 ${ }^{\circ} \mathrm{C}$ for 4 hours. The half cell is reduced in $95 \% \mathrm{~N}_{2}-5 \% \mathrm{H}_{2}$ for 2 hours before applying the cathode. The cathode and gold wires at the anode were applied before fixing the cell in a homemade testing cell holder and fired at $925^{\circ} \mathrm{C}$ for 3 hours. Hydrogen was flowed at the anode site during the cathode calcination to avoid the oxidation of the support at high temperatures. The cathode was then infiltrated followed by hand paint the current collector and wires. The cell was then heated at $700{ }^{\circ} \mathrm{C}$ to oxidize the infiltrated precursor and start cell measuring. 


\section{Chapter 3: Metal support fabrication}

In this chapter the use of 430L (iron-based) stainless steel (SS-430L) and nickel oxide as supporting layer are discussed. Sub-section 3.1 and 3.2 in this chapter covers the fabrication of porous metal support, sintering, and characterization methods for SS-430L and nickel oxide candidates, respectively. The fabrication methods explain the pore former selection and percentage for open pores. Sintering includes cell burn-out profiles and shrinking behavior. With respect to the characterization methods, various techniques are implemented: the open pores are measured by the Archimedes method, the shrink behavior is characterized by measuring the green pellets with a caliper before and after sintering, and for the comprehension of the microstructure SEM images were taken before and after the reduction of the metal-supported cell.

\section{1 - Stainless steel metal support}

\subsection{1 - Pore former selection}

As part of the shrinkage match between the metal support and electrolyte, different pore formers were used to accomplish this goal. Table 1 bellow shows different pore formers that were used in order to keep good porosity for the metal support and electrolyte shrinkage matching.

Table 1: Pore former advantages and disadvantages.

\begin{tabular}{|l|l|l|l|}
\cline { 2 - 4 } \multicolumn{1}{c|}{} & Starch from Rice & $\mathrm{NaCl}$ & $\mathrm{NaAlO}_{2}$ \\
\hline Advantage & -Burn easily. & -Can stand high & - Higher melting point \\
& -Helps in the shrinkage. & temperature & $(1600 \mathrm{C})$ \\
& & $(700 \mathrm{C})$. & -Provide acceptable \\
& & -Is soluble in & porosity $(30$ to $40 \%)$ \\
& & water. & -Do not burn away at \\
& & $\begin{array}{l}\text {-Helps in the } \\
\text { shrinkage. }\end{array}$ & $\begin{array}{l}\text { sintering } \\
\text { temperatures. }\end{array}$ \\
\hline Disadvantage & -Burn at low & - It melts above & -Do not provide \\
& temperatures. & $700 \mathrm{C}$ & reasonable shrinkage. \\
\hline
\end{tabular}



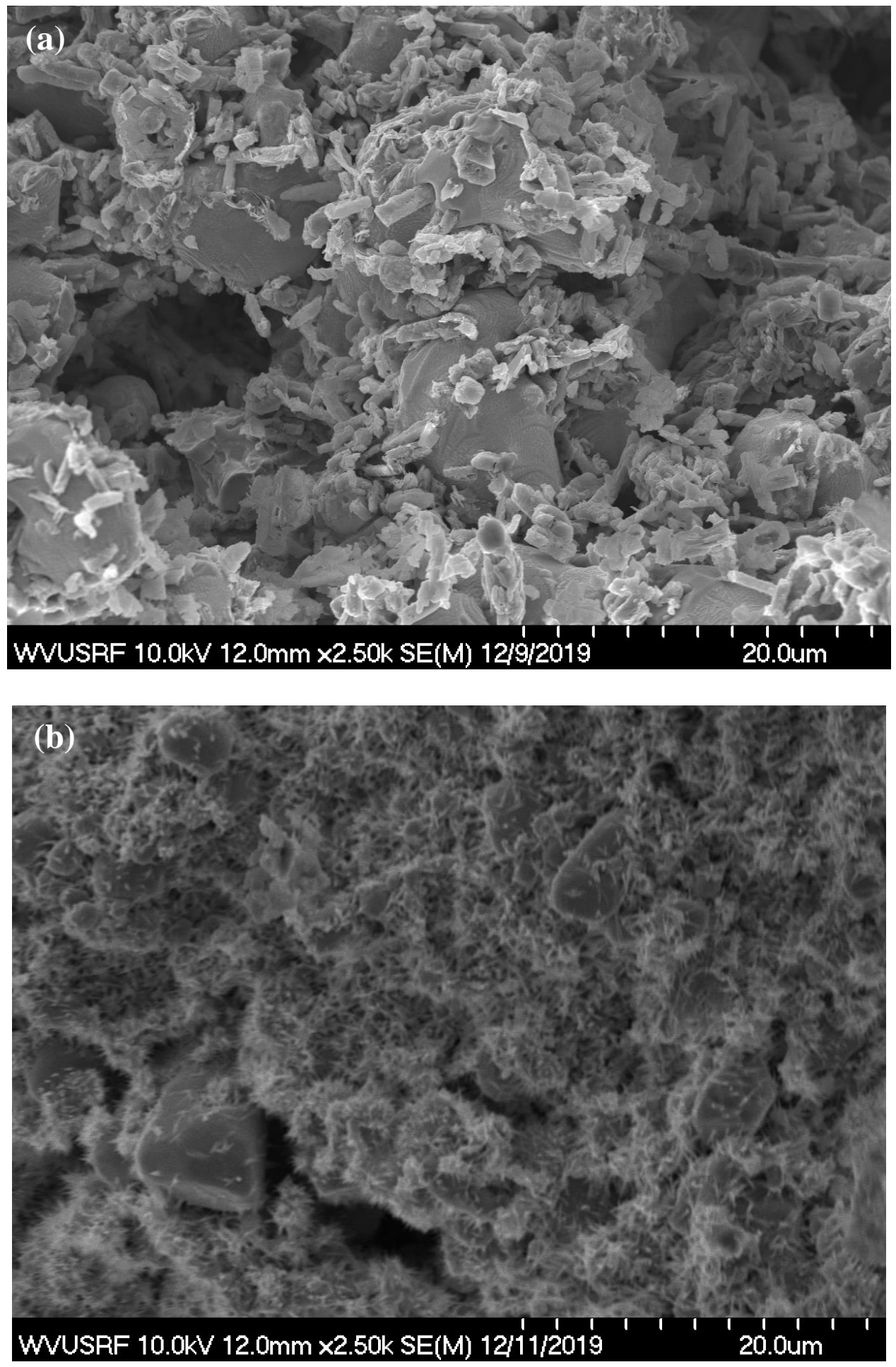

Figure 4: Iron-based Stainless-steel supported cell structure using NaAlO2 as pore former. (a) After sintering. (b) After cell wash.

$\mathrm{NaAlO}_{2}$ benefits pore formation in the structure due to its high temperature resistance above the cell sintering temperature. At the same time because of the 
high-temperature resistance, it also prevents the stainless steel (metal support) particles to bond together acting like a barrier between them, as shown in Figure 4. Therefore, after the removal of the pore former, it was observed that some of the particles did not bond (Figure 4-b), creating weak points inside the structure, which leads to major cracks. Also, does not provide much aid for the support to match the electrolyte shrinkage.

As for the $\mathrm{NaCl}$ and Starch from rice, the complete densification of the support comes from the suggestion of these pore formers particle size are much smaller than the support particles. These pore formers create tiny paths that were later close by the support particles during the sintering process. In addition, the use of $\mathrm{NaAlO}_{2}$ or $\mathrm{NaCl}$ end up corroding the cell a couple of days (see Figure 5) after sintering and washing process for its removal due to sodium is known to be corrosive, therefore if particles of these pore formers stay at the boundaries between particles or in the support surfaces, can potentially corrode the cells.

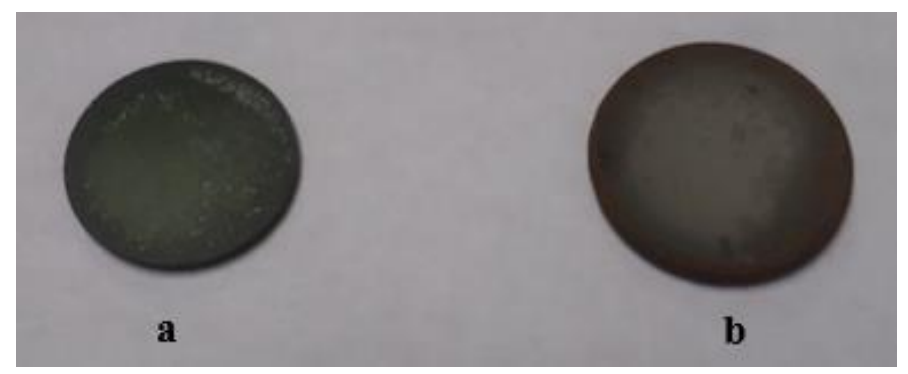

Figure 5: Stainless steel oxidation a couple of days after sintered using different pore formers: (a) $\mathrm{NaCl}$ and (b) $\mathrm{NaAlO}_{2}$.

\subsection{2 - Sintering process}

One main concern about the use of stainless steel as supporting cells is its melting point and oxidation at temperatures below or close to the electrolyte densification temperature. Stainless steel supported cells were sintered under reducing atmosphere since the temperature required to achieve electrolyte densification overpass the oxidation resistance hence affecting the shrinkage of the cell. Green pellets made with 430L stainless steel powder were mix with different concentrations of pore former and pressed obtaining a $16 \mathrm{~mm}$ in diameter, $1 \mathrm{~mm}$ height pellet. The pellets were then sintered in nitrogen and argon atmosphere at 
$1350{ }^{\circ} \mathrm{C}$ for $4 \mathrm{hr}$. to observe its shrinking behavior following the burn-out profile from table X. The shrinkage measurements after sintering are shown in Figure 6. As seen in the figure, sintering stainless steel in argon provide better shrinkage, densification, and size match with the electrolyte rather than in nitrogen, same as reported by Mariappan, R. et al. [11].

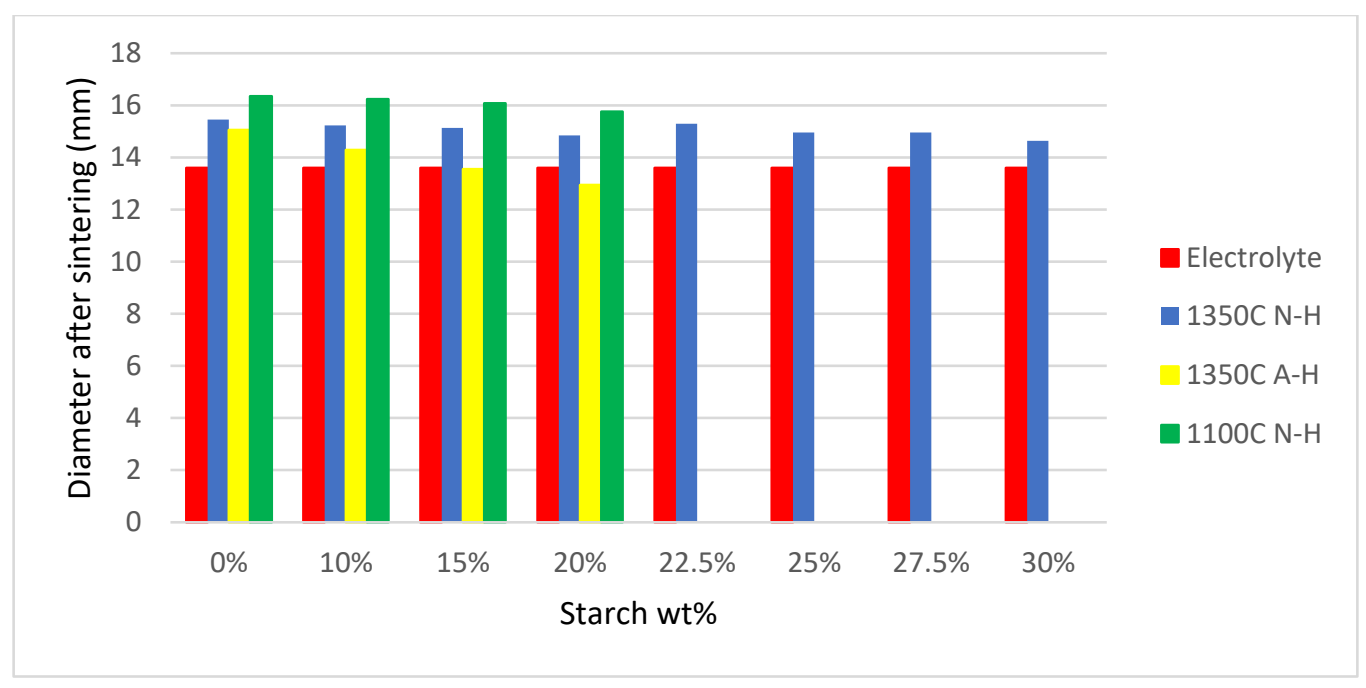

Figure 6: Stainless steel support shrinkage after sintering using different amounts of starch as pore former.

Even when with $15 \mathrm{wt} \%$ starch it was able to match considerably the electrolyte and support under argon atmosphere, the stainless steel was almost complete dense, hence no pathways for fuel transport were form.

\section{2 - Nickel oxide metal support}

\subsection{1 - Shrinkage and Pore formation}

The use of pore former for the support play two important roles:

(1) The formation of pathways or channels for gas flows through the support bulk.

(2) Helps in the shrinkage and size matching between layers.

As part of this investigation, a $16.46 \mathrm{~mm}$ disc nickel oxide pellets with different weight percent of starch were fabricated and sintered at different temperatures as well as the function layer and electrolyte. Results are shown in Figure 7. 


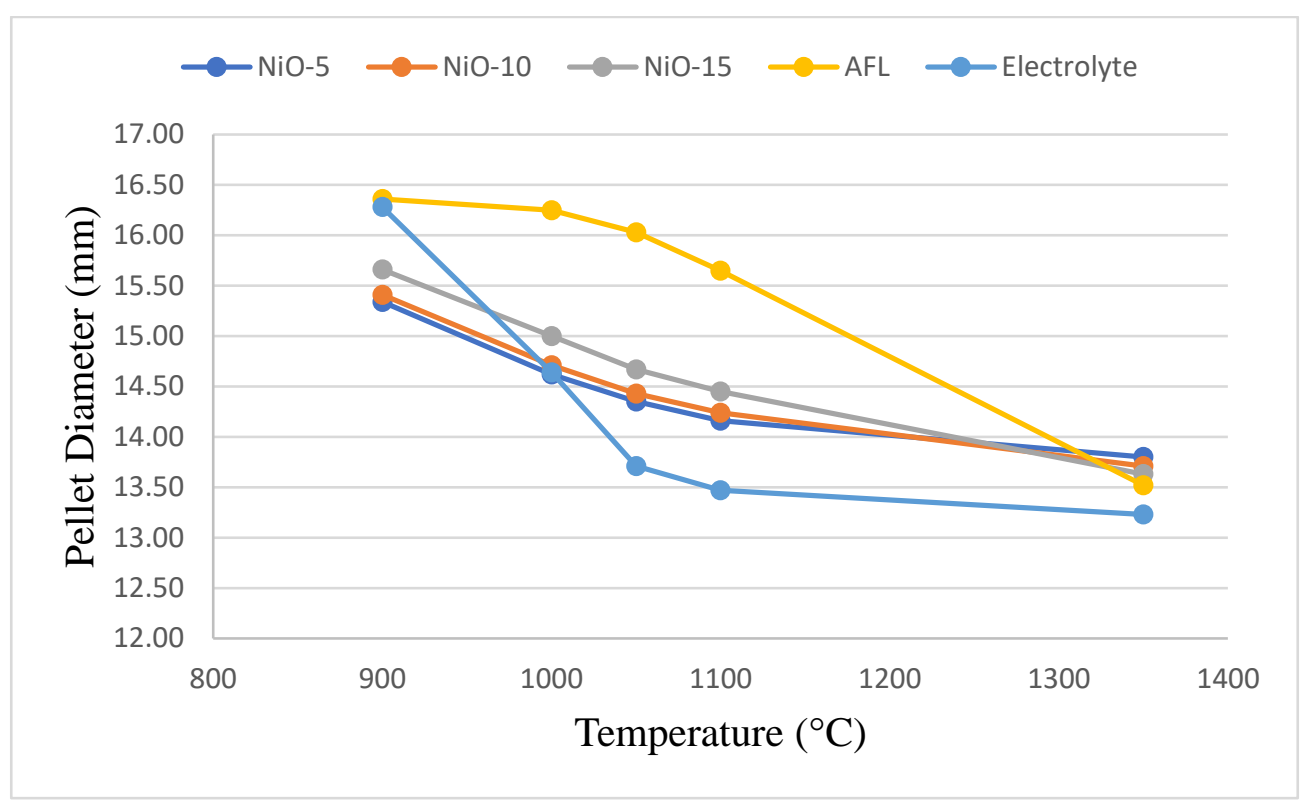

Figure 7: Cell layers shrinking analysis.

The, why the cells tend to curve in a concave shape can be answered from Figure 7. When looking at the pellets size at $900{ }^{\circ} \mathrm{C}$ it is noticed that nickel pellets shrink much more than the anode function and electrolyte layers. As higher temperature is needed to allow the AFL and the electrolyte to shrink, this could explain the concave shape after sintering.

The measurement of open pores is an important parameter which ensures pathways for sufficient fuel gas to travel from the support site to the anode for electrochemical reaction. Based on literature reviews, a material with more than $20 \%$ open pores may be considered a good candidate structure for SOFCs at intermediate temperature [12]. Archimedes method was used to estimate the open porosity of the cell support. For the nickel oxide pellet $10 \mathrm{wt} \%$ starch content, the estimated open porosity are around 49 percent after sintered at $1300{ }^{\circ} \mathrm{C}$ for 4 hours in air.

It can also be observed how the AFL with a nickel oxide to BZCYYb composition ratio of 6:4 takes an even higher temperature for this layer to start shrinking.

\subsection{2 - Sintering and Support reduction}

Unlike stainless steel supporting cells, nickel oxide did not require to undergo in a reducing atmosphere during sintering as it can be reduced moments before cell operation. Even though nickel oxide has this advantage over stainless steel materials, due to the difference in the thermal expansion coefficient of nickel and 
BZCYYb (electrolyte), the formation of cracks inside the support or at the layer interface threatening the integrity of the cell.

As we look back to Figure 7, can be suggested that the addition of BZCYYb stops or delay the growth of nickel particles inside the layer. This behavior was also observed by Vafaeenezhad, S. et. al., where he reported that the addition of ceramic materials to the $\mathrm{Ni}$ supported cells improve the microstructure and mitigate $\mathrm{Ni}$ growth inside the support and shows better shrinking match between layers as well [13]. A fuel cell with a modified support ( $\mathrm{NiO}$ support with 5wt\% BZCYYb) was fabricated. From Figure 8, it is observed how the addition of the ceramic prevents the cell from curving. Since the amount of BZCYYb is too little compare with the amount of nickel the support can still be considered a metal supporting cell.

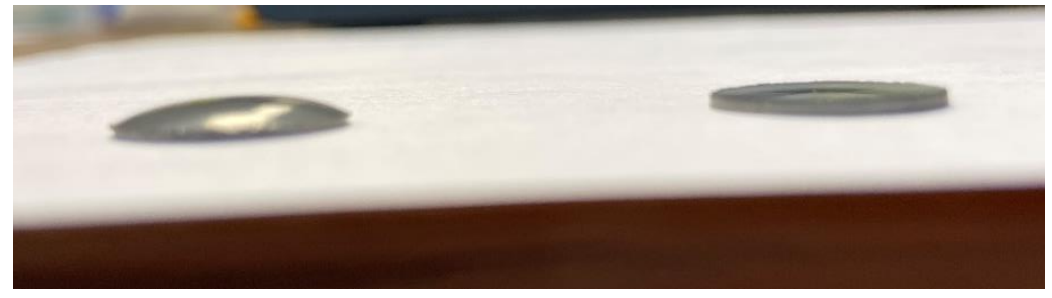

Figure 8: Fuel cell final shape after sintering. Nickel support cell without BZCYYb (left sample), Nickel supported cell with 5wt\% BZCYYb (right sample).

Another important consideration in the fabrication process of the cells, is the sintering setup. After different trial and error, it was possible to sinter a dense electrolyte while keeping the desirable support porosity free of cracks or delamination between layers. The main concern during the sintering is the delamination of the layers during the burnout of the organic binder and pore former. As the binder burnout from the different layers may cause internal pressure by heating the furnace too fast. The temperature profile that satisfies the proper sintering of the nickel supported cells goes as follow: (i) The furnace is heated at $500{ }^{\circ} \mathrm{C}$ with a ramping of $2{ }^{\circ} \mathrm{C} / \mathrm{min}$ and hold for $10 \mathrm{~min}$ to slowly burn the pore former while reducing the pressure build-up inside the layers, (ii) After that, the temperature is increased at $900{ }^{\circ} \mathrm{C} / \mathrm{min}$ at a ramping of $2{ }^{\circ} \mathrm{C} / \mathrm{min}$ to allow the binder to burnout, (iii) Followed that, the temperature is again increased at $1300{ }^{\circ} \mathrm{C} / \mathrm{min}$ and hold for 4 hours and then cool down naturally to room temperature without 
opening the furnace. This sintering profile was repeated several times with different batches to ensure repeatability.

Posterior to coating and sinter the cathode, the cell was attached in a homemade testing holder and sealed with a ceramic bond (see Figure 10). The support is then reduced from $\mathrm{NiO}$ to $\mathrm{Ni}$ at $650{ }^{\circ} \mathrm{C}$ using wet hydrogen. Prior to reduction, the nickel supported section is purged with nitrogen to remove the oxygen. The volume concentration associated with the reduction opens sufficient porosity in the support to enable adequate fuel transport as can be seen in Figure 9.

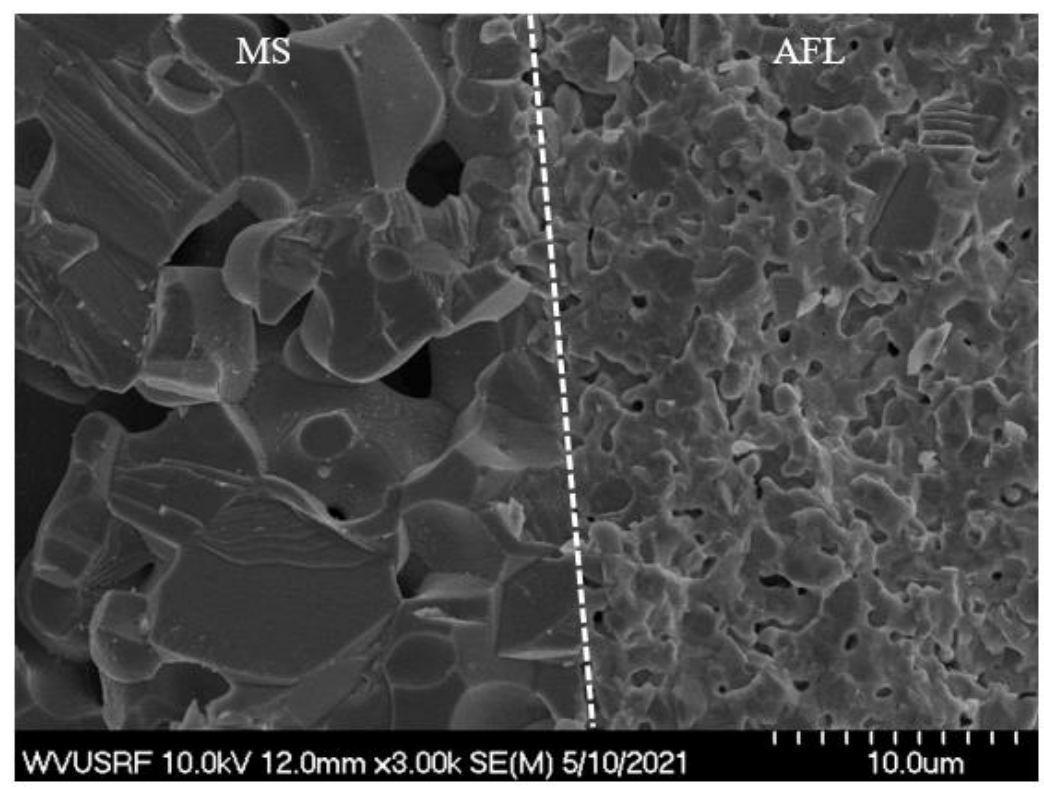




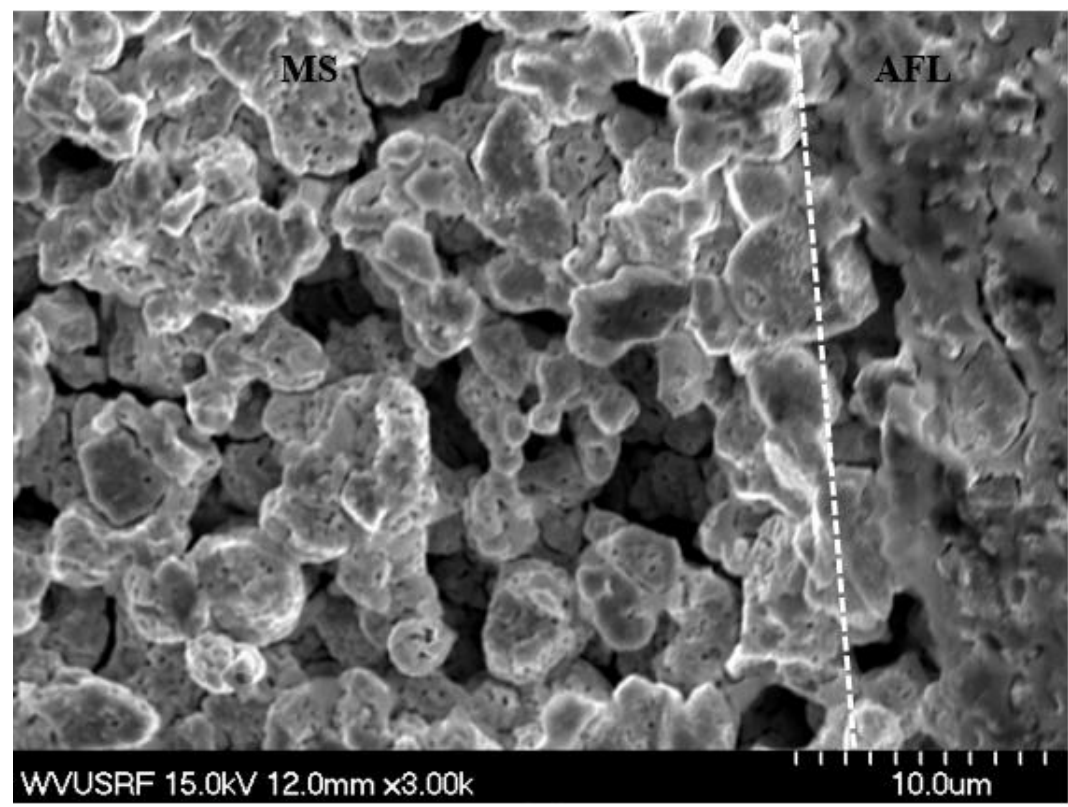

Figure 9: SEM cross-section image of Metal support (MS) and Anode function layer (AFL) interface. (a) Before reduction and (b) After reduction.

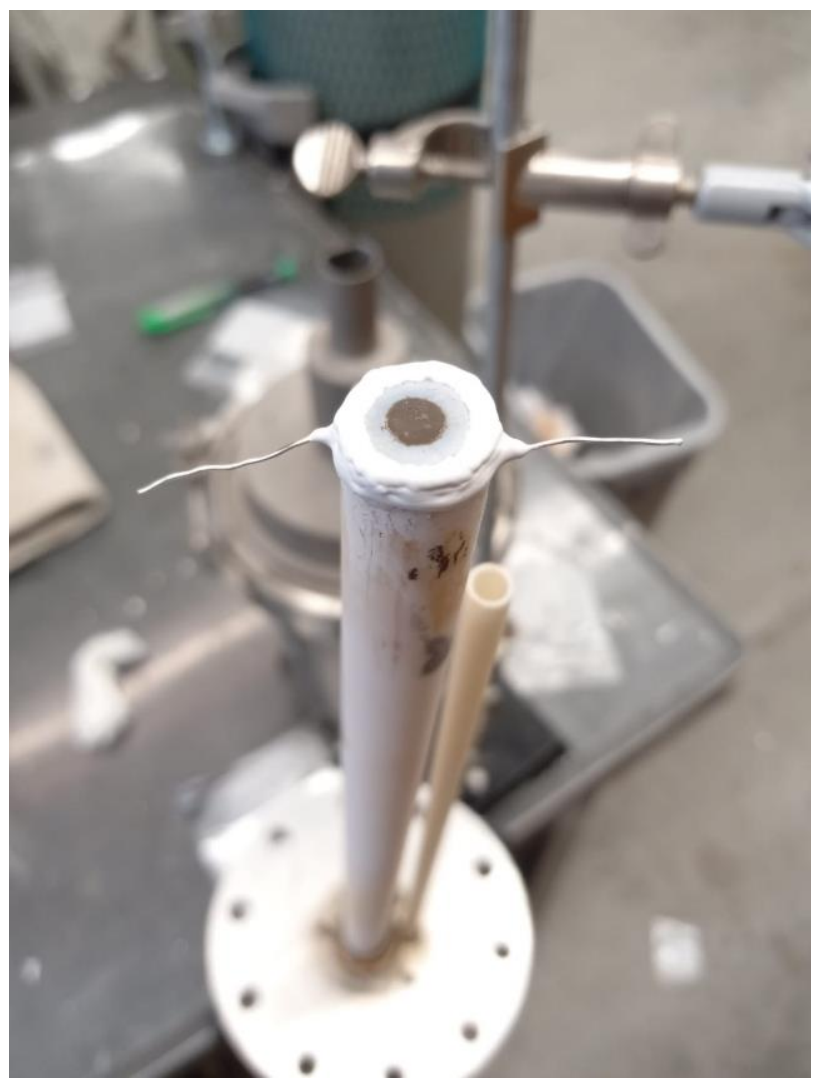

Figure 10: Cell holder. 
This method of reduction ends up breaking the samples once the cell OCV reached 1.0 V. It was suggested that the reason behind could be the ceramic sealing. The issue lays on the good property of the sealing to bond with nickel. As nickel oxide changes in volume because of the reduction process, the ceramic bond locks in place nickel particles that are in the process of being reduced may cause cracks in the microstructure, which leads to gas leaks and the destruction of the sample before completing the reduction. In order to determine that the sealing was the cause of the samples from breaking, fuel cells without the cathode were reduced in $95 \% \mathrm{~N}_{2}$ $5 \% \mathrm{H}_{2}$ at $700{ }^{\circ} \mathrm{C}$ for 2 hours. As a result, a crack-free pure nickel metal-supported cell was achieved. After this second reduction method, the sample shows a stable OCV (see Figure 11). By doing this experiment, it was confirmed that reducing the support after sealing the sample could be the source of cracks in the structure during reduction.

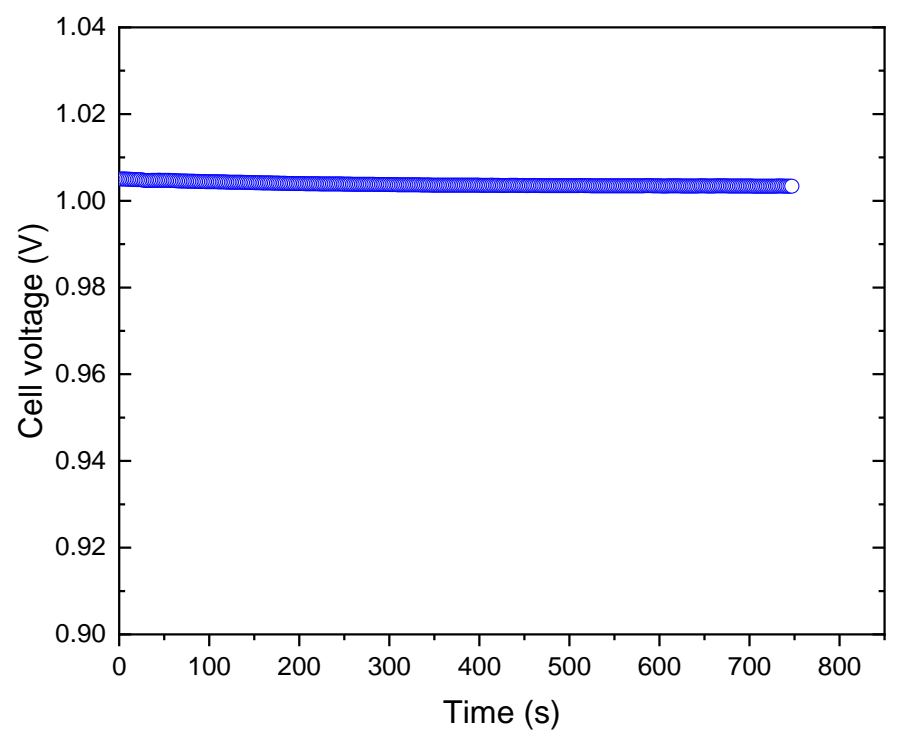

Figure 11: Electrical performance of a single metal-supported SOFC at 700C.

\section{3 - Chapter Summary}

Some downsides that are still under development nowadays using stainless steel metal-supported cells are (i) the mismatch of the thermal expansion with the electrolyte, (ii) the melting temperature for this kind of steel is lower than the 
temperature required for the electrolyte to densify (iii) the need of a reducing atmosphere during sintering which avoid the support for oxidating and sinter properly increase the cost of fabrication. As more time is needed it for the development and research of stainless-steel metal-supported cells, nickel oxide supported cell is considered as a feasible approach for metal-supported solid oxide cell fabrication and development. 


\section{Chapter 4: Electrolyte enhancement and Cathode surface modification by infiltration method}

\section{1 - Effect of non-stoichiometric $B_{1+x} Z C Y Y b$}

In this section, non-stoichiometric BZCYYb electrolyte was fabricated by sol-gel technique as a method to improve its proton-conducting property. As perovskite-type SOFC's electrolytes, they need to be sinter at temperatures above $1250{ }^{\circ} \mathrm{C}$ to achieve densification as reported elsewhere $[14,15]$. Due to the need for these high sintering temperatures, phase structure can be compromised by the Ba evaporation during sintering. For this study, the electrolyte stoichiometry for the A-site was changed $(x=0,0.05$, and 0.1). Figure 12 shows the XRD patterns of $\mathrm{NiO}|\mathrm{NiO}-\mathrm{BZCYYb}| \mathrm{BZCYYb}$ half cells after been sinter at $1300{ }^{\circ} \mathrm{C}$ for $4 \mathrm{~h}$ in air by hyper-stoichiometric the A-site $(0,5$, and $10 \mathrm{~mol} \%)$. This result indicated that the slight A-site change in the BZCYYb did not change the structure of the perovskite, and no secondary phase was generated.

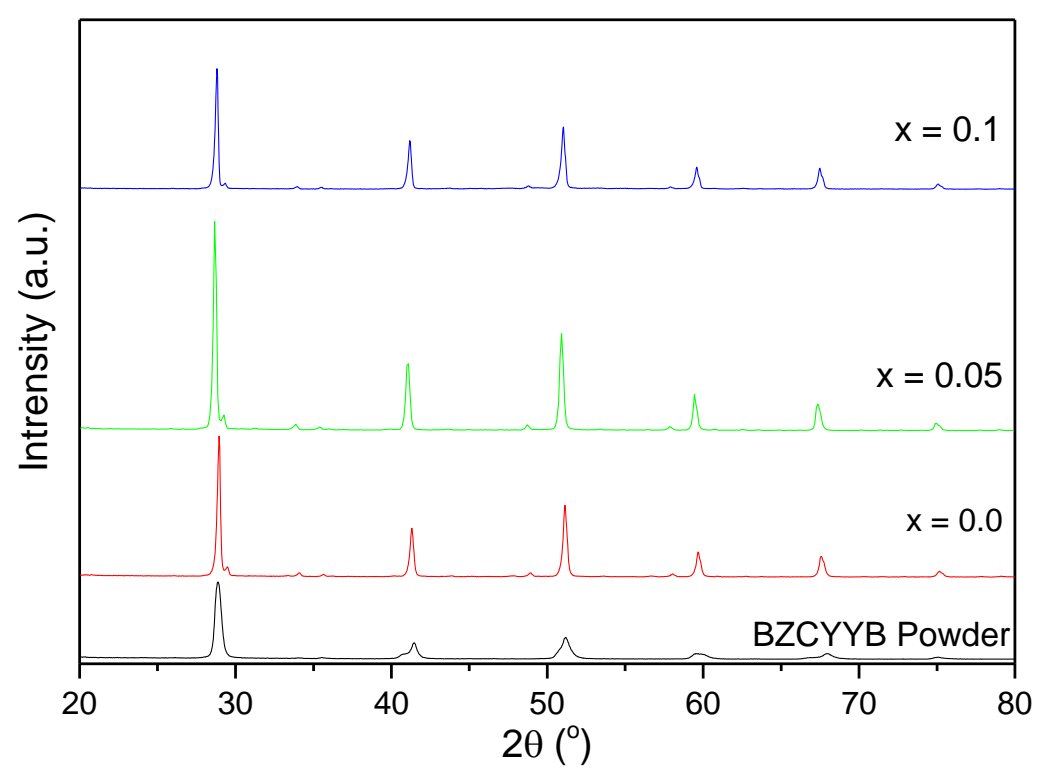

Figure 12: XRD patterns of $\mathrm{B}_{1+\mathrm{x}} \mathrm{ZCYYb}(\mathrm{x}=0,0.05,0.1)$ after sintering at $1320^{\circ} \mathrm{C}$ for $4 \mathrm{~h}$. 
As the formation of extra oxygen vacancies is expected to be generated by the excess of Barium at the A-site, an improvement in proton conductivity was expected at intermediate temperatures due to protons activation energy. Electrochemical impedance was measured at $650{ }^{\circ} \mathrm{C}$ in order to validate this assumption.

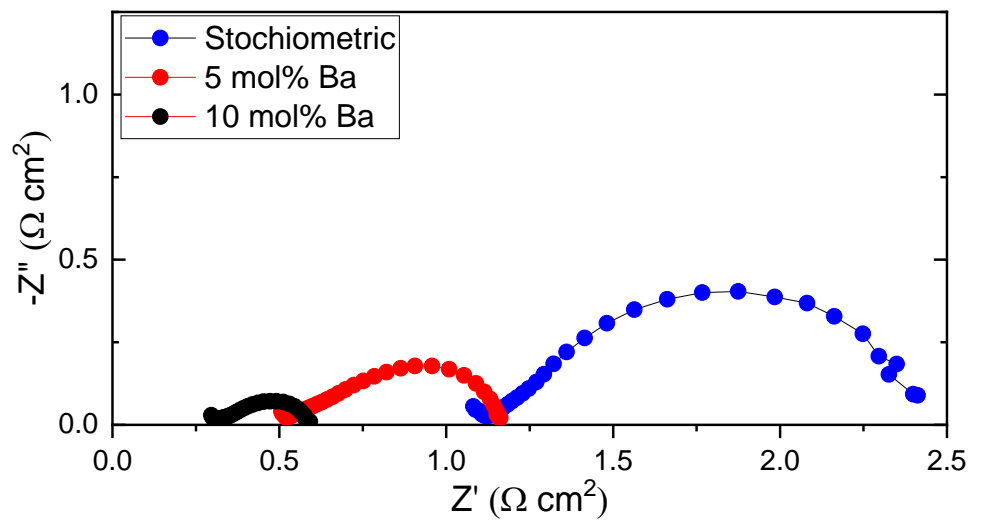

Figure 13: Electrochemical impedance spectroscopy (EIS) of fuel cell with different A-site concentrations in the electrolyte layer at $650{ }^{\circ} \mathrm{C}$.

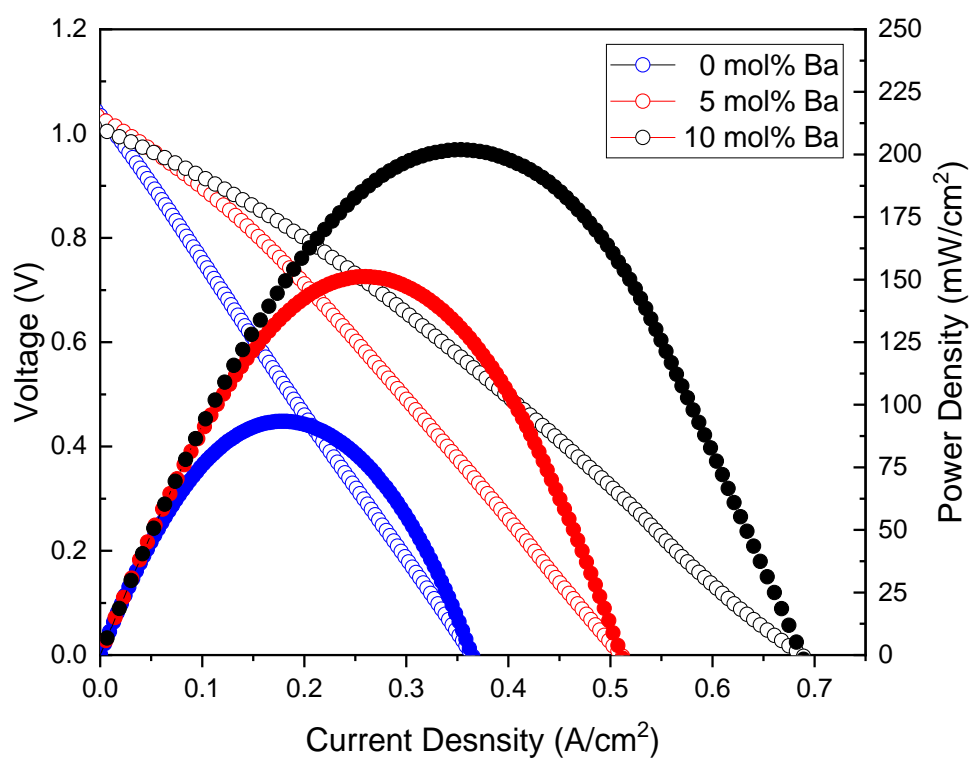

Figure 14: I-V curve and Power density plot at $650^{\circ} \mathrm{C}$. 
Consequently, Figure 13 demonstrates that the addition of Barium in fact improves the conductivity from 1.11 (stochiometric BZCYYb) to 0.3 (10 mol\% hyperBarium). Hence, an improvement in the power density is also expected to happen as well. This slight change resulted in an improvement in performance of almost 2 times the stochiometric BZCYYb electrolyte showing a power peak density from $93 \mathrm{~mW} / \mathrm{cm}^{2}$ to $201 \mathrm{~mW} / \mathrm{cm}^{2}$ at $650{ }^{\circ} \mathrm{C}$ (see Figure 14) using PNO-BZCYYb composite cathode.

\section{2 - Surface modification by Infiltration method}

Due to the reduction of the operational temperatures, the cell performance can suffer an increase in electrolyte resistance as well the difficulty of the oxygen reduction reaction in the cathode. This led to the development of techniques that are able to increase the cell performance by modifying the cathode surface in order to promote the ORR.

\subsection{1 - Infiltration/ impregnation}

Infiltration or impregnation process has been widely used in surface modification of SOFC components [16]. By Infiltration, it means the deposition of nanoparticles into an electrode porous structure using an aqueous or organic solution. This process allows the soluble metal salts to be carried to the electrode structure through solutions [16, 17]. This method permits the infiltration of materials that cannot be otherwise used in a conventional electrode fabrication process due to high reactivity with the other components of the SOFC, since the infiltration process separates the formation temperature of the catalytic active phase from the high sintering temperature required to the biding interface between electrolyte and electrode [16]. Also, it could improve the electrochemical catalytic activity and long-term stability performance by infiltrating desirable loading amount to form a thin conformal coating through the whole porous electrode structure [18]. Even though this method required multiple infiltration cycles in order to reach the designed amount of loading, it has still been a simple and cost- 
effective process for a wide range of materials [19-21]. Since certain metal nitrates can be dissolved into the same solvent, sometimes it is needed to infiltrate the precursors separately to reach designed stoichiometry.

Shen, J. et al., reported that the modification of LSM with SDC effectively improved the electrocatalytic for ORR reaching an ASR of $0.18 \Omega \mathrm{cm}^{2}$ at $700{ }^{\circ} \mathrm{C}$ [22]. Akbari, Z. et al., also reported an enhancement in $\mathrm{LSMO}_{4}$ electrode performance by impregnating $\mathrm{La}_{2} \mathrm{NiO}_{4}(\mathrm{LNO})$ solution which is a mixed ionic and electronic conductor (MIEC). His study showed a remarkable enhancement by decreasing the polarization resistance from 26.2 to $2.5 \Omega \mathrm{cm}^{2}$ at $650{ }^{\circ} \mathrm{C}$ and providing alternate reaction pathways with lower activation energies of the ORR under OCV conditions [23]. This opens the possibility of a wide range of single or combined candidates that could double or triple the performance of any cathode composition.

\subsection{2 - Infiltration Process}

Usually, the aqueous solution is divided in three components: (i) the precursor, (ii) the solvent, and (iii) the surfactant. The precursor for infiltration is frequently in the form of nitrates since they can be decomposed after firing the sample. In the case of multiple precursors or metal salts, it is important to know the solubility of each component because this can limit the solution concentration. One common practice is that the precursors are dissolved in either (i) deionized water, (ii) ethanol, or (iii) in a combination of both $[19,24]$. In addition to that, citric acid, $\mathrm{NH}_{4} \mathrm{OH}$, X100, etc. can be used as surfactant $[19,25]$. The addition of surfactant helps the dissolution process and prevents its precipitation [20]. Some also promote the wetting of the solution to the electrode inner surface to provide even coverage [20]. In most cases, after infiltration, the sample is vacuumed for several minutes to remove air pockets inside the backbone structure [20,21]. After each infiltration process, the sample were calcined in air from 350 to $600^{\circ} \mathrm{C}$ to burn out all the nitrate and organics components, leaving only the metal oxide particles [20, 26]. The samples are sintered at elevated temperatures so the infiltrate particles can crystalize and bond to the backbone electrode. 


\subsection{3 - Precursor selection and characterization}

In separate aqueous solutions, Cobalt, Neodymium, and Praseodymium nitrates were prepared as the precursors. Each solution has a concentration of 0.2 mol/L mixed with citric acid in a weight ratio 1:1 in DI water to provide better impregnation of the solution to the pores of electrode.

In order to achieve a good deposition of the precursors, after each infiltration, the sample was vacuumed to remove the air inside the electrode bulk, securing that the precursor penetrated all the way into the backbone. The sample was heated at $500^{\circ} \mathrm{C}$ for $15 \mathrm{~min}$ to evaporate the solvent and burn the organic material. This process was performed in PNO-BZCYYb symmetric cells to which a different amount of the precursors was infiltrated by repeating the infiltration process. The cells are identified as shown in Table 2 . The symmetric cells were then fired at $850^{\circ} \mathrm{C}$ for 3 h. Silver paste was applied to both sides of the cells as the current collector and heated for $30 \mathrm{~min}$ at $550^{\circ} \mathrm{C}$. Figure 15 shows a post-mortem PNO-BZCYYb electrode cross sectional infiltrated with Cobalt.

Table 2: Infiltrated cell identification.

\begin{tabular}{|l|c|c|}
\hline Precursor & Identification name & Number of cycles \\
\hline \multirow{3}{*}{ Neodymium } & Nd-3 & 3 \\
\cline { 2 - 3 } & Nd-4 & 4 \\
\cline { 2 - 3 } & Nd-5 & 5 \\
\hline \multirow{3}{*}{ Cobalt } & Co-3 & 3 \\
\cline { 2 - 3 } & Co-4 & 4 \\
\cline { 2 - 3 } & Co-5 & 5 \\
\hline \multirow{3}{*}{ Praseodymium } & Pr-3 & 3 \\
\cline { 2 - 3 } & Pr-4 & 4 \\
\cline { 2 - 3 } & Pr-5 & 5 \\
\hline
\end{tabular}

The electrochemical impedance spectroscopy (EIS) measurements for the symmetrical cells were carried out at frequencies from $1 \mathrm{MHz}$ to $0.1 \mathrm{~Hz}$ in $3 \% \mathrm{P}_{\mathrm{H} 2 \mathrm{O}}$ in OCV condition. Measurements were taken from 600 to $700{ }^{\circ} \mathrm{C}$ in steps of $50{ }^{\circ} \mathrm{C}$ as a preliminary test as a performance filter. To focus on the electrode polarization resistance the potential drop due to ohm resistance has been subtracted from the Nyquist plot (see Figure 17). 


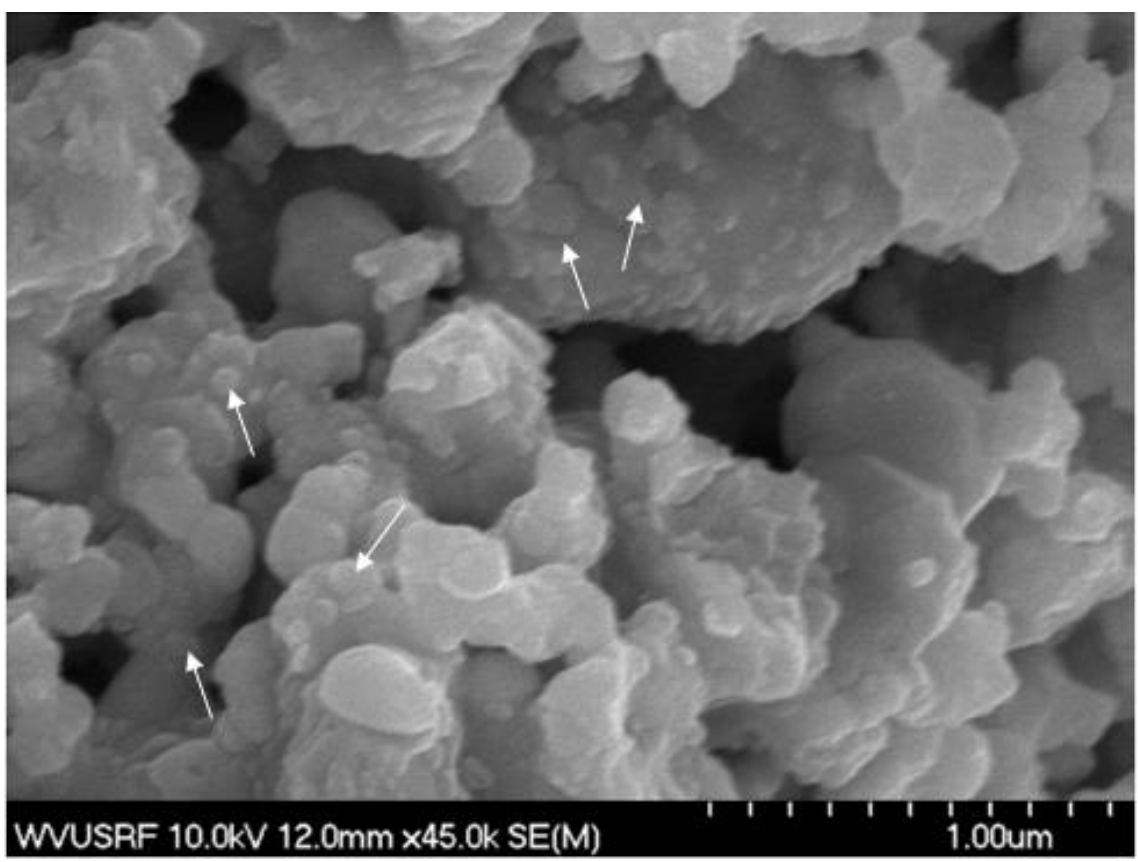

Figure 15: SEM image of PNO-BZCYYb cross section infiltrated with CoO.

After measuring the EIS to the infiltrated symmetric cells, the results indicate the potential benefit of infiltrating highly active materials for IT-SOFCs. These measurements revealed a decrease of the effective charge transfer resistance in the cathode which are caused by the precursor activity in the charge transfer and the increase of surface area. Note that Praseodymium and Cobalt infiltrated cells performed better than the Neodymium infiltrated cells which is still showing better performance than pristine PNO-BZCYYb, making them a feasible candidate for enhancing the cathode performance at intermediate temperatures. The best infiltrated cells for each candidate at $650{ }^{\circ} \mathrm{C}$ generated a polarization resistance of $0.41,0.25$, and $0.24 \Omega \mathrm{cm}^{2}$ from Nd-4, Pr-5, and Co-5, respectively. Even when cobalt is considered one of the best catalytic materials for SOFC applications it is noteworthy to highlight that Praseodymium is also capable to closely match Cobalt performance. As both materials achieved the expected performance, further studies were carry-out with Co infiltrated PNO-BZCYYb cathode. Figure 16 shows a single MS-SOFC cell performance comparison after the infiltration of cobalt using 
wet hydrogen and air as fuel and oxidant, respectively at $650{ }^{\circ} \mathrm{C}$. A power density of $355 \mathrm{~mW} / \mathrm{cm}^{2}$ after infiltration was obtained.

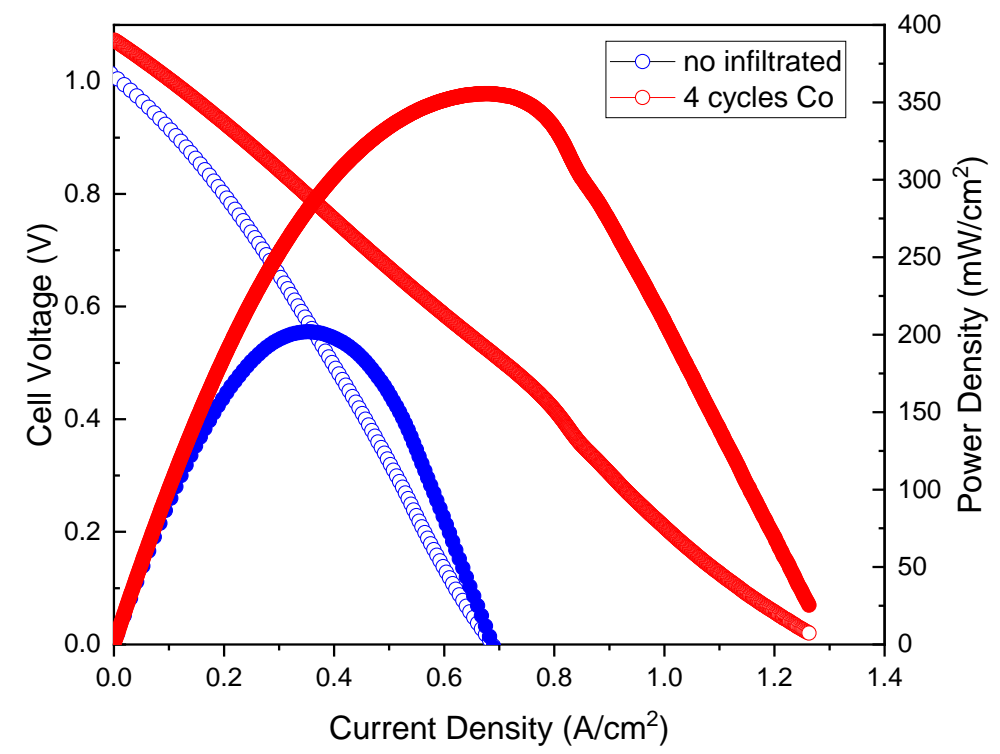

Figure 16: Performance of improved single cell at $650 \mathrm{C}$ with $\mathrm{H}_{2}$ and air as fuel and oxidant, respectively.

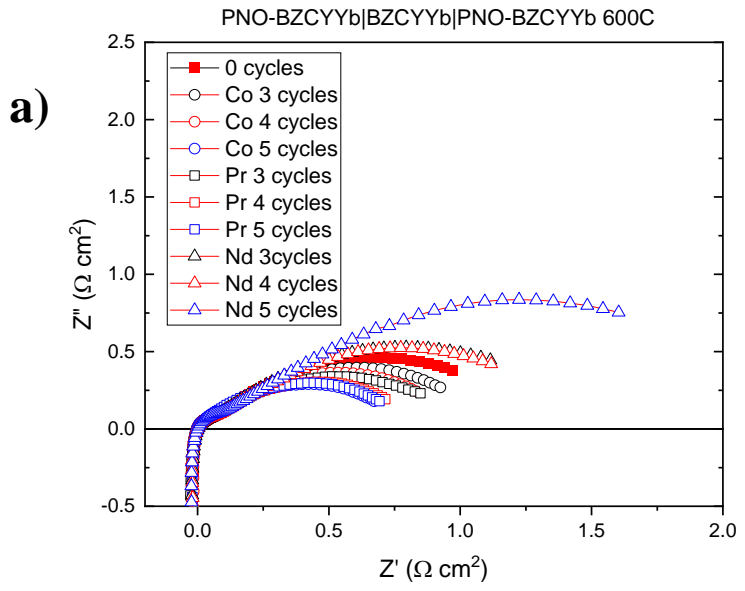



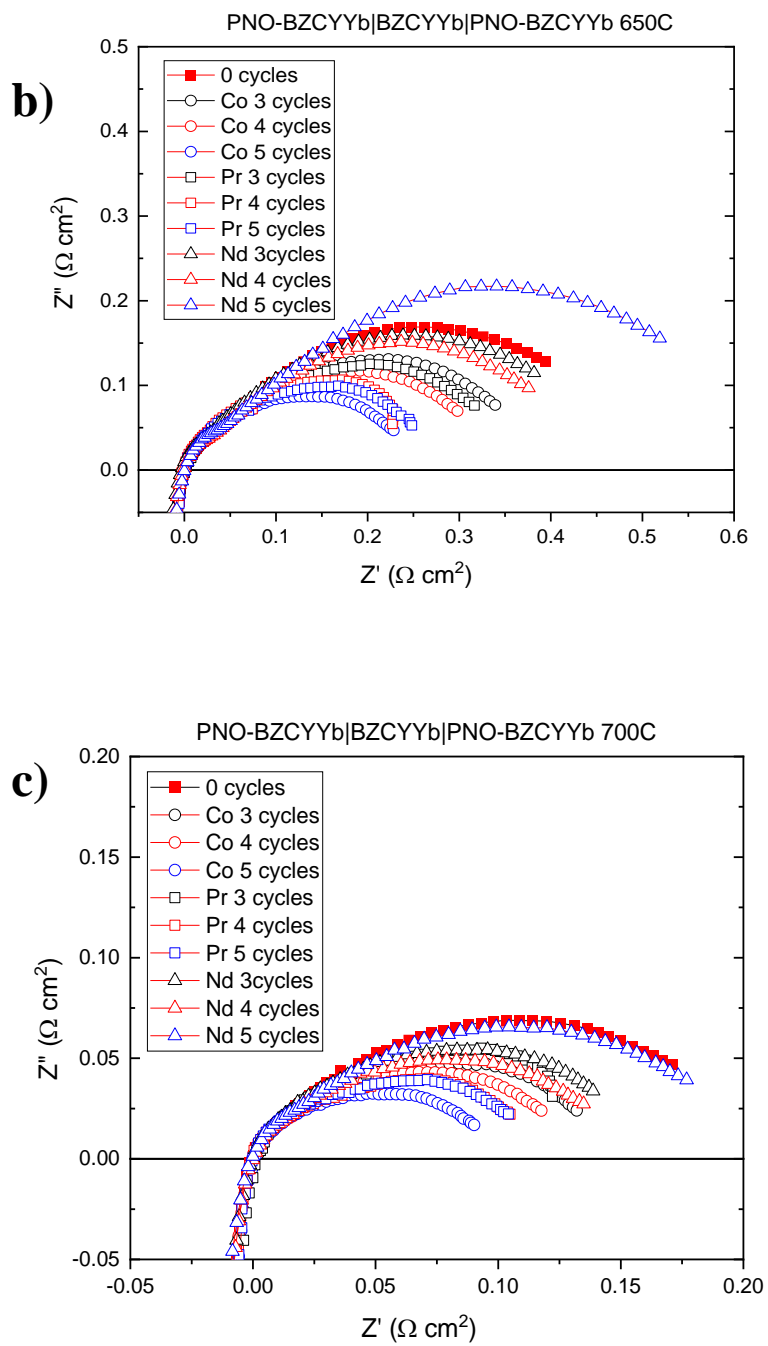

Figure 17: Polarization resistance behavior of infiltrated PNO-BZCYYb electrode in $3 \%$ steam at different temperatures. (a) $600{ }^{\circ} \mathrm{C}$, (b) $650{ }^{\circ} \mathrm{C}$, and (c) $700{ }^{\circ} \mathrm{C}$. 


\section{3 - Steam interference in ORR}

Different from O-SOFC, the $\mathrm{H}-\mathrm{SOFC}$ will produce water at the cathode side. In addition to air from the atmosphere in the cathode, high concentrations of steam will be present during operation. The steam may also affect the ORR process in the cathode reaction by interfering with oxygen adsorption. To study the effect of humidity on the ORR kinetics, the cathode was measured using different partial pressures of water and temperature. EIS measurements were taken after flowing air through a temperature-programmed bubbler. 5, 10, 15, and 20 percent steam in air were used. Figure 18 shows the EIS of Co infiltrated PNO-BZCYYb cathode in different $\mathrm{P}_{\text {H2O }}$ measured under $\mathrm{OCV}$ at $650{ }^{\circ} \mathrm{C}$ which is selected as the cell operational temperature.

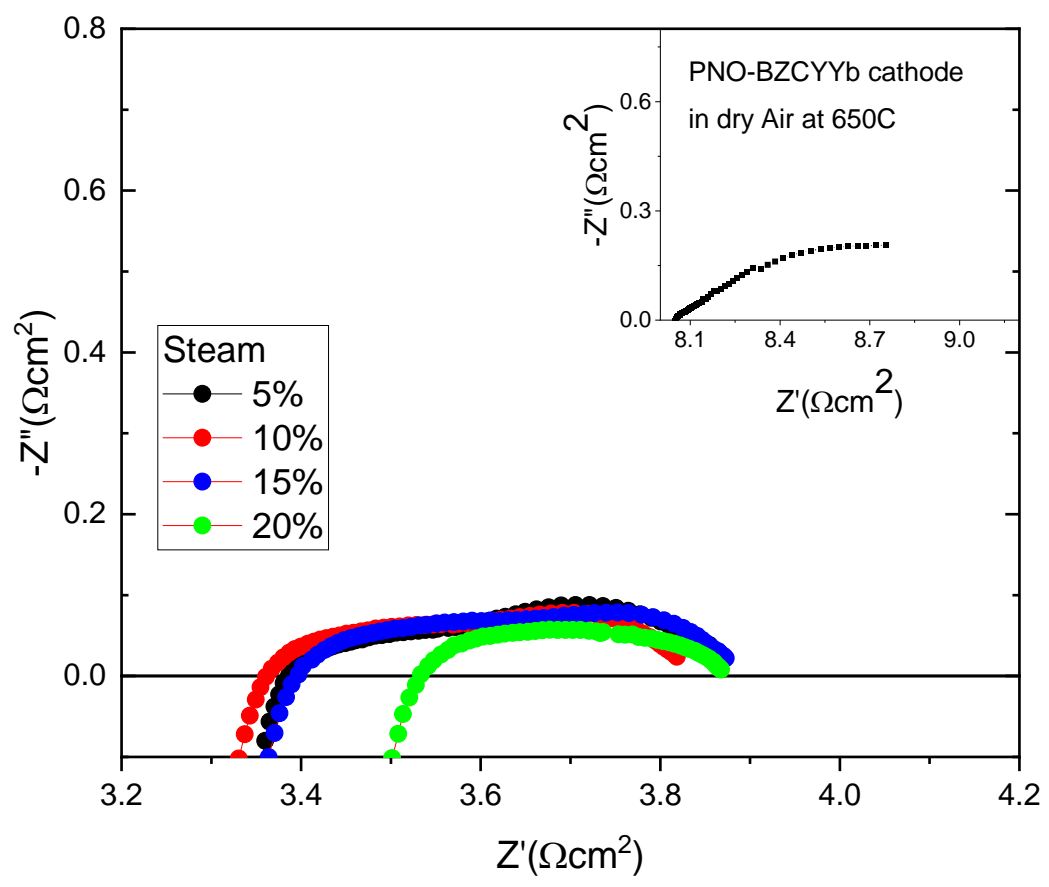

Figure 18: EIS measurement for Co infiltrated PNO-BZCYYb symmetric cell in dry air, $5 \%, 10 \%, 15 \%$ and $20 \%$ steam at $650{ }^{\circ} \mathrm{C}$. 
When $5 \%$ of water vapor was fed, something to notice is a reduction in ohmic resistance from 8 to $3.4 \Omega \mathrm{cm}^{2}$, which suggests a change from $\mathrm{O}$-conduction to $\mathrm{H}$ conduction. At the time of measuring the EIS at higher steam concentration, it shows not much of a difference in terms of ohmic resistance improvement which takes us to the conclusion that above $5 \%$ steam $\mathrm{H}$-conductivity was almost saturated. In $20 \%$ steam at $650{ }^{\circ} \mathrm{C}$, the polarization resistance of $0.17 \Omega \mathrm{cm}^{2}$ was achieved.

The incorporation of these concentrations shows that by increasing the steam up to 20 percent, the cathode polarization resistance was gradually reduced as showed in Figure 18. The increase in performance observed occurs because more protons are present, therefore, increasing the proton conduction rate in the Cobalt infiltrated PNO-BZCYYb cathode bulk. 20 percent steam has proven a maximization in performance without affecting the ORR in the symmetrical cell.

\section{4 - Chapter Summary}

In this chapter, the effect of hyper-stochiometric $\mathrm{Ba}$ on the electrolyte for proton-conducting enhancement, improvement of the cathode by the incorporation of single oxides through infiltration method and cathode performance characterization has been investigated. An enhancement of the electrolyte was obtained with the increase of barium content promoting better proton conduction at intermediate temperatures. The infiltration method has proved to be a feasible technique for cathode improvement showing a remarkable reduction of the polarization resistance as well as the ORR. The best performance observed at 650

${ }^{\circ} \mathrm{C}$ was Cobalt infiltrated in PNO-BZCYYb composite electrode with a Rp of 0.17 $\Omega \mathrm{cm}^{2}$ in $20 \%$ humidified air. It was observed that by performing multiple cycles of the infiltration, candidate's materials that showed lower activity can achieve or get close to more active but expensive materials just with the increase of the infiltration. 


\section{Chapter 5: Ammonia direct feeding}

\section{1 - Advantage of ammonia utilization}

Although hydrogen-powered fuel cell has proved an efficient pathway for energy conversion, the use of ammonia has become an attractive alternative as fuel. In terms of $\mathrm{CO}_{2}$ emission, ammonia is a good indirect hydrogen storage material because it does not contain carbon and therefore will not release $\mathrm{CO}_{2}$ when used as fuel. While hydrogen-powered cell shows outstanding performance, its low volumetric energy density $(8.5 \mathrm{MJ} / \mathrm{l})$ and storage still a problem to solve. On the other hand, ammonia has a higher volumetric energy density (12.7 MJ/1) [27]. Storage-wise, ammonia can be liquefied at $0.8 \mathrm{MPa}$ at $20{ }^{\circ} \mathrm{C}$, which can be massproduced faster and easier than hydrogen production. Even though ammonia is hazardous to handle, is much less flammable than hydrogen, therefore much safer for its transportation and storage.

The direct utilization of ammonia for proton-conducting SOFCs offers potential cost and environmental benefits over oxygen-ion SOFC which are fueled by hydrocarbon fuels. Due to catalysts like $\mathrm{Ru}, \mathrm{Ni}, \mathrm{Fe}$, etc., ammonia can be internally decomposed in a two-stage reaction. At the anode, ammonia is cracked to produce hydrogen and nitrogen, protons are generated at the anode and transported through the proton-conducting electrolyte to the cathode where they react with surface oxygen ions generated electrochemically from oxygen.

This chapter discusses the direct utilization of ammonia as a fuel for H-SOFC fuel cells in intermediate temperatures.

\section{2 - Fuel cell measurements}

For this section, Nickel supported cells were assembled using the best fabrication parameters reported in the previous chapters in this thesis. Figure 19 
shows the effect of increasing temperature on the open-circuit voltage (OCV) of the same single cell on ammonia and hydrogen, respectively. From this figure, it can be seen that the OCV for either ammonia or wet hydrogen decreased by the increase of temperature. The lower partial pressure of hydrogen because the coproduction of nitrogen explains why MS-SOFC operation under ammonia exhibits a lower OCV. The OCVs were 1.08 and $0.988 \mathrm{~V}$ at $650{ }^{\circ} \mathrm{C}$ when operating on wet hydrogen and ammonia, respectively.

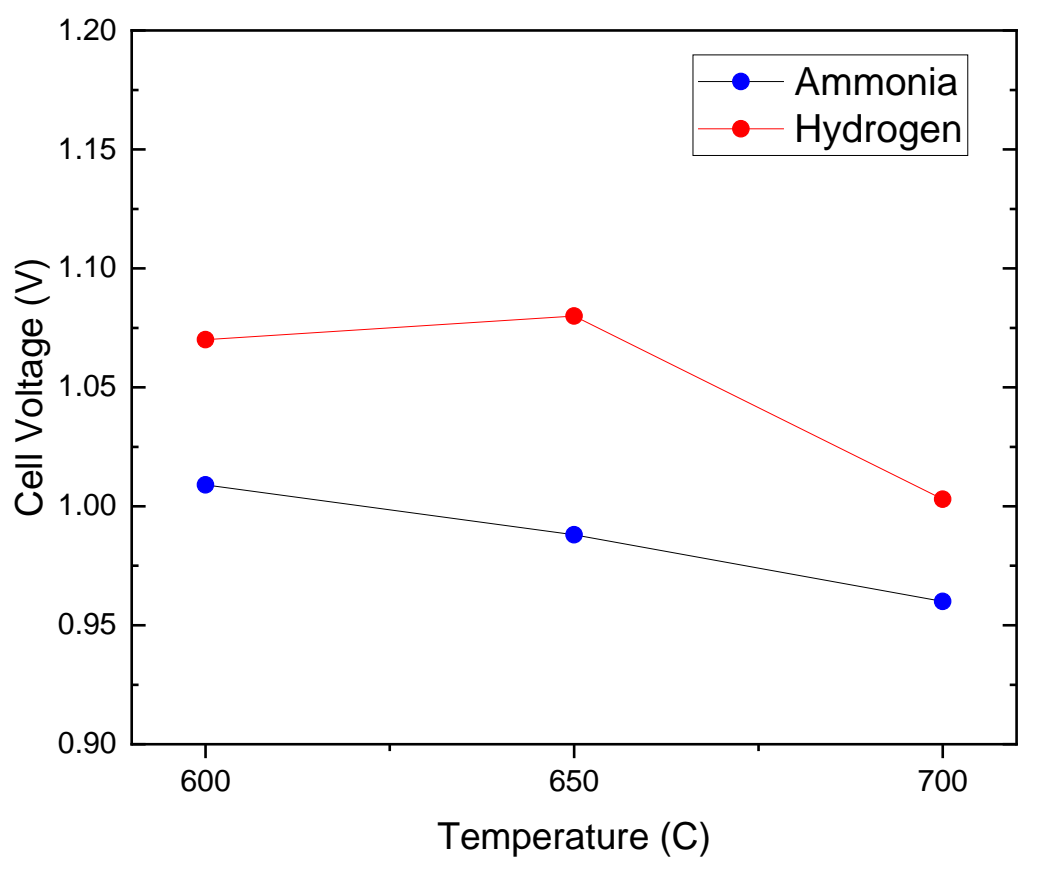

Figure 19: OCVs of Metal-Supported SOFC with ammonia or wet hydrogen as fuel and air as oxidant at different temperatures.

Figure 20 shows the I-V curves together with the power density of the MS-SOFC fueled with ammonia. As the voltage and current density is not linear as it was expected, this suggested a weak interface between the electrode and the electrolyte. This conclusion is made based on the fact the MS-SOFC fueled with wet hydrogen showed the same behavior (see Figure 21). Even though with ammonia as fuel and air as oxidant, a maximum power density of 232 and $343 \mathrm{~mW} / \mathrm{cm}^{2}$ were obtained at 650 and $700{ }^{\circ} \mathrm{C}$, respectively. In addition to the measurements taken with 
ammonia, the same cell was tested at the same temperatures with wet hydrogen as fuel, the results are shown in Figure 21. The maximum power density obtained under this atmospheric condition were 355 and $429 \mathrm{~mW} / \mathrm{cm}^{2}$ at 650 and $700{ }^{\circ} \mathrm{C}$, respectively.

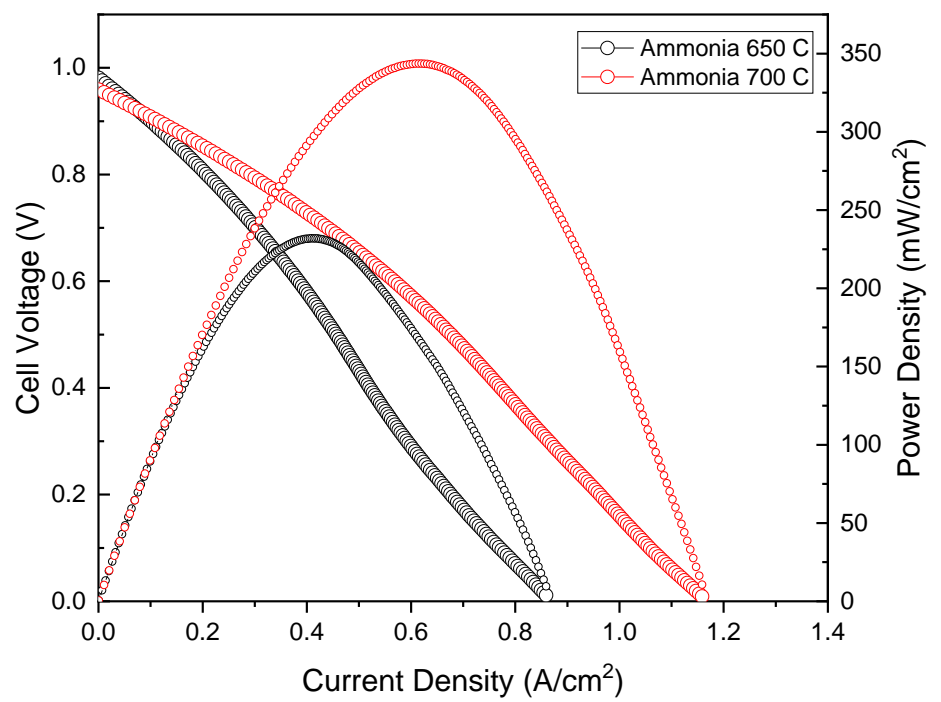

Figure 20: I-V curve of MS-SOFC with ammonia as fuel and air as oxidant at different temperatures.

Figure 22 gives the comparisons of the impedance spectra of a single cell fueled by ammonia and hydrogen at different temperatures. The polarization resistance of 0.24 , and $0.135 \Omega \mathrm{cm}^{2}$ at 650 , and $700{ }^{\circ} \mathrm{C}$, respectively, were obtained using ammonia as fuel. Compared with 0.25 and $0.15 \Omega \mathrm{cm}^{2}$ at $650,700{ }^{\circ} \mathrm{C}$, respectively with wet hydrogen it was observed a similar polarization resistance. This similarity at these temperatures were expected due to the ammonia cracking process is more active at these temperatures. Because the EIS measured was using the same fuel cell, after switching the fuel from hydrogen to ammonia, the cathode side was already humidified by the steam generated due to the water produced by the electrochemical reaction, it explains why the polarization resistance measured in ammonia is slightly lower than under hydrogen. Figure 23 shows Ni-supported SOFC cross sectional after operating in ammonia. 


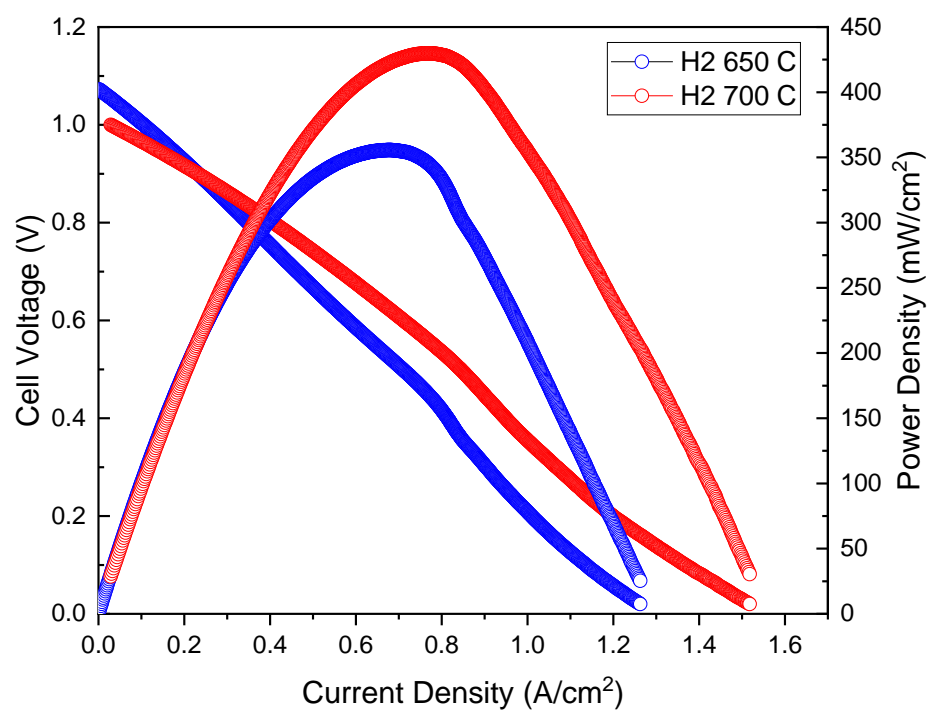

Figure 21: I-V curve of MS-SOFC with wet hydrogen $\left(\sim 3 \% \mathrm{H}_{2} \mathrm{O}\right)$ as fuel and air as oxidant at different temperatures.

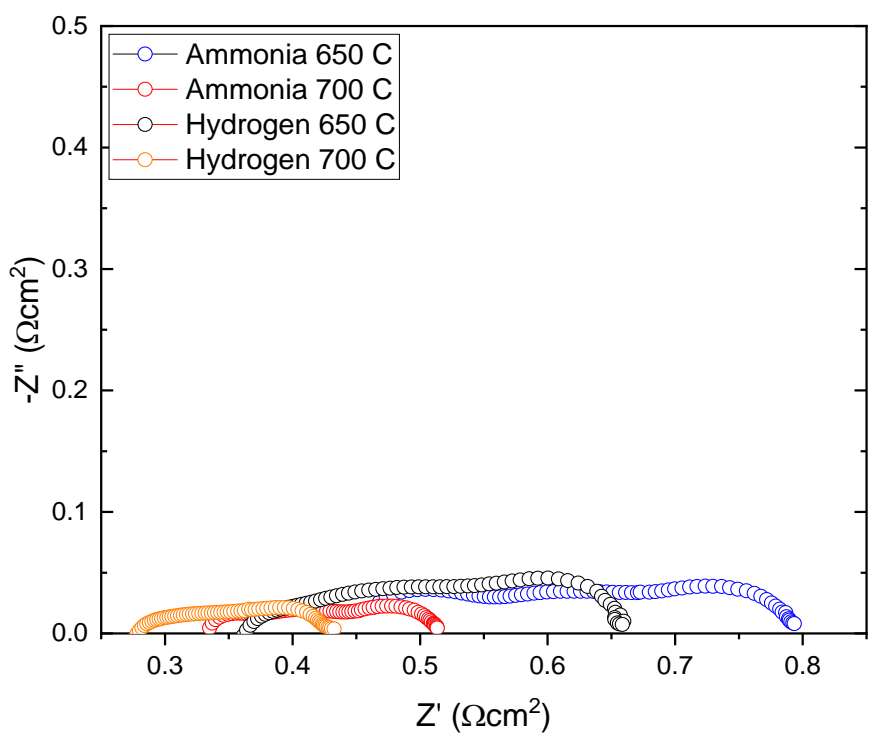

Figure 22: Comparisons of impedance spectra of single cell with ammonia and hydrogen as fuel under OCV conditions at 650 , and $700{ }^{\circ} \mathrm{C}$. 


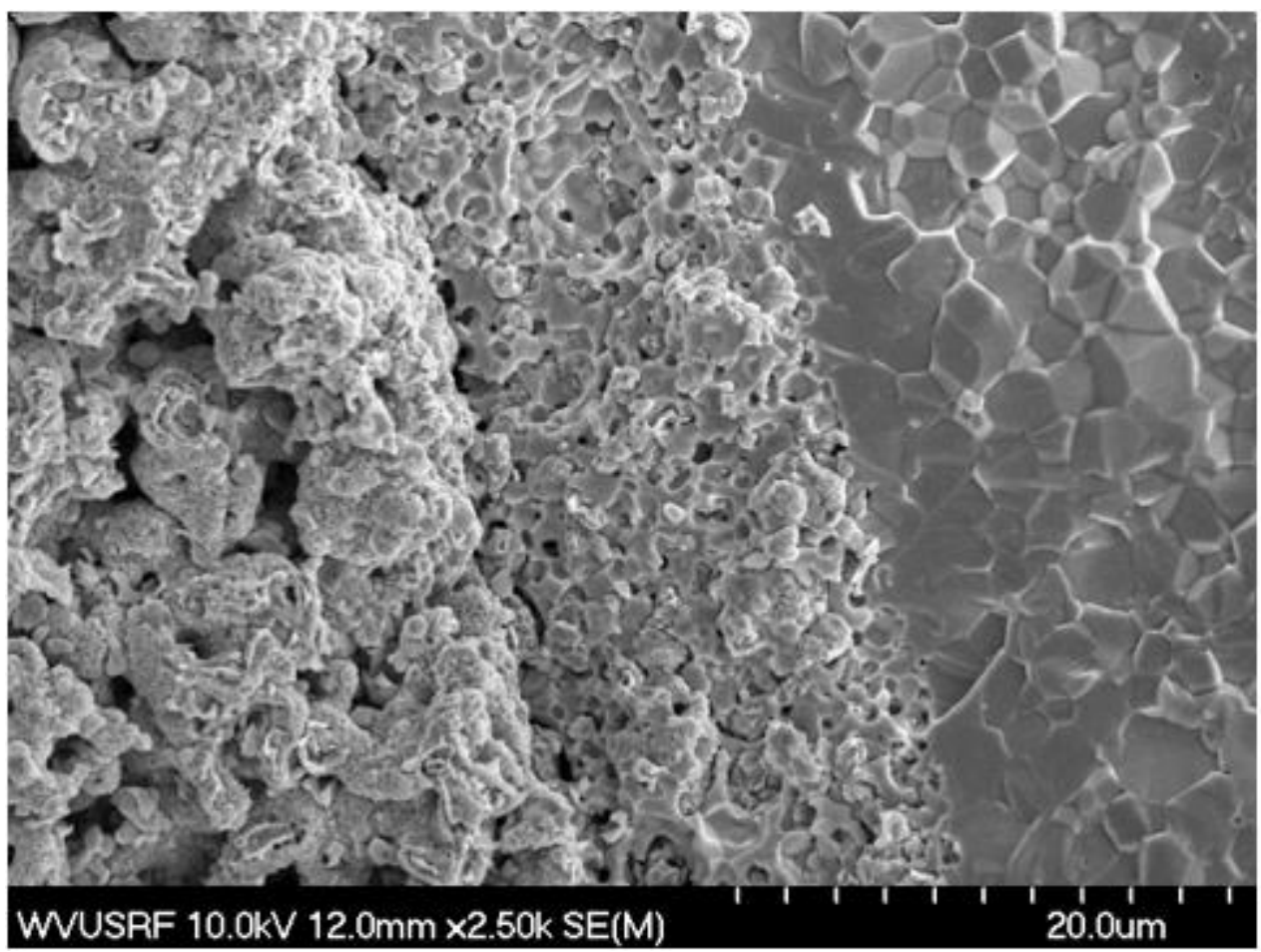

Figure 23: SEM image of nickel metal-supported solid oxide fuel cell after operating in ammonia.

\section{3 - Chapter Summary}

In this chapter, the direct use of ammonia in a metal-supported H-SOFC has been analyzed. It was demonstrated that ammonia may be the substitute fuel for hydrogen. Although the low partial pressure of hydrogen after the ammonia decomposition, which is a limitation factor, shows a reduction in the cell OCV was observed as reported in the literature. Hence, showing a maximum power density peak of 231 , and $343 \mathrm{~mW} / \mathrm{cm}^{2}$ at 650 , and $700{ }^{\circ} \mathrm{C}$, respectively. 


\section{Chapter 6: Conclusion}

In this thesis, the investigation and development of a metal-supported proton-conducting solid oxide fuel cell have been conducted. For the metal-support layer, two materials were investigated. As a result, the use of nickel oxide was chosen over 430L stainless steel. As nickel powder is already oxidized, this facilitates the fabrication and sintering process as it can be reduced to nickel metal just before operation. This brings back to attention the use of nickel oxidesupported cells as a feasible approach for metal-supported solid oxide cell fabrication and development. The addition of $10 \mathrm{wt} \%$ of starch as pore former gives the cell around $40 \%$ open pores which allows multiples pathways for the gas to travel across the supporting layer. To even out the support shrinking with the anode function layer and electrolyte, it was found that the addition of $5 \mathrm{wt} \%$ of BZCYYb (electrolyte) to the support mitigated the support over shrinking during the sintering.

With the idea of improving the ORR, the incorporation of different precursors through the Infiltration technique were analyzed. This technique gives the advantage of infiltrating any possible material as neodymium, praseodymium, cobalt, etc., (used in this study) to the cathode structure regardless its thermal expansion coefficient. As it is to be expected, cobalt provided a considerable enhancement to the cathode ORR as the polarization resistance showed a reduction from 0.5 to $0.24 \Omega \mathrm{cm}^{2}$ at $650{ }^{\circ} \mathrm{C}$ under $3 \%$ humidified air. Even though highly active materials as cobalt and praseodymium, it was also demonstrated that less active materials compared to the ones mentioned above, can still provide an increase in performance over pristine cells.

No less important, the direct utilization of ammonia as a fuel for protonconducting solid oxide fuel cells (H-SOFCs) was also investigated as a new source of hydrogen. In contrast to $\mathrm{H}_{2}$-fueled MS-SOFC, $\mathrm{NH}_{3}$-fueled MS-SOFCs showed a reduction in their performance due to the low partial pressure of hydrogen after the decomposition of $\mathrm{NH}_{3}$ into nitrogen and hydrogen. A maximum power density 
peak of 231 , and $343 \mathrm{~mW} / \mathrm{cm}^{2}$ at 650 , and $700{ }^{\circ} \mathrm{C}$, respectively. With further improvement in the fabrication of MS-SOFC, an optimization in performance can be reached undoubtedly. 


\section{References}

1. Demin, A. and P. Tsiakaras, Thermodynamic analysis of a hydrogen fed solid oxide fuel cell based on a proton conductor. International Journal of Hydrogen Energy, 2001. 26(10): p. 1103-1108.

2. Ishak, F., I. Dincer, and C. Zamfirescu, Thermodynamic analysis of ammonia-fed solid oxide fuel cells. Journal of Power Sources, 2012. 202: p. 157-165.

3. Yin, S.-F., et al., Investigation on the catalysis of COx-free hydrogen generation from ammonia. Journal of Catalysis, 2004. 224(2): p. 384-396.

4. Muroyama, H., et al., Ammonia decomposition over Ni/La2O3 catalyst for on-site generation of hydrogen. Applied Catalysis A: General, 2012. 443: p. 119-124.

5. Okura, K., et al., Ammonia decomposition over nickel catalysts supported on rare-earth oxides for the on-site generation of hydrogen. ChemCatChem, 2016. 8(18): p. 2988-2995.

6. Yang, J., et al., Electrochemical and catalytic properties of $\mathrm{Ni} / \mathrm{BaCeO}$. 75Y0. 25O3- $\delta$ anode for direct ammonia-fueled solid oxide fuel cells. ACS applied materials \& interfaces, 2015. 7(13): p. 7406-7412.

7. $\mathrm{Li}, \mathrm{W}$., et al., High performing triple-conductive Pr $2 \mathrm{NiO} 4+\delta$ anode for proton-conducting steam solid oxide electrolysis cell. Journal of Materials Chemistry A, 2018. 6(37): p. 18057-18066.

8. $\quad\langle$ Perovskite Oxide for Solid Oxide Fuel Cells.pdf>.

9. $\quad$ O'Hayre, R., Fuel Cell Fundamentls. 2016: John Wiley \& Sons.

10. Molouk, A.F.S., et al., Electrochemical and catalytic behaviors of Ni-YSZ anode for the direct utilization of ammonia fuel in solid oxide fuel cells. Journal of the Electrochemical Society, 2015. 162(10): p. F1268.

11. Mariappan, R., S. Kumaran, and T.S. Rao, Effect of sintering atmosphere on structure and properties of austeno-ferritic stainless steels. Materials Science and Engineering: A, 2009. 517(1-2): p. 328-333.

12. Rose, L., et al., Characterization of Porous Stainless Steel 430 for Lowand Intermediate-Temperature Solid Oxide Fuel Cell (SOFC) Substrates. International Journal of Green Energy, 2009. 6(6): p. 638-645.

13. Vafaeenezhad, S., et al., Development of proton conducting fuel cells using nickel metal support. Journal of Power Sources, 2019. 435.

14. Liu, Y., et al., Enhanced sinterability of BaZr0.1Ce0.7Y0.1Yb0.1O3- $\delta$ by addition of nickel oxide. Journal of Power Sources, 2011. 196(23): p. 9980-9984.

15. Nguyen, N.T.Q. and H.H. Yoon, Preparation and evaluation of BaZr0.1Ce0.7Y0.1Yb0.1O3- $\delta$ (BZCYYb) electrolyte and BZCYYb-based solid oxide fuel cells. Journal of Power Sources, 2013. 231: p. 213-218.

16. Ding, D., et al., Enhancing SOFC cathode performance by surface modification through infiltration, in Energy and Environmental Science. 2014. p. 552-575.

17. Qiu, P., Review on core-shell structured cathode for intermediate temperature solid oxide fuel cells, X. Yang, Editor. 2020, Internaltional Journal of Hydrogen. p. 23160-23173. 
18. Tang, H., et al., Electrochemical performance of nanostructured LNF infiltrated onto LNO cathode for BaZr0.1Ce0.7Y0.2O3-4-based solid oxide fuel cell, in International Journal of Hydrogen Energy. 2018, Elsevier Ltd. p. 19749-19756.

19. Choi, S., et al., High Performance SOFC Cathode Prepared by Infiltration of Lan $+1 \mathrm{NinO} 3 n+1(n=1,2$, and 3) in Porous YSZ, in Journal of The Electrochemical Society. 2011, The Electrochemical Society. p. B995.

20. Kiebach, R., et al., Infiltration of SOFC Stacks: Evaluation of the Electrochemical Performance Enhancement and the Underlying Changes in the Microstructure, in Fuel Cells. 2016. p. 80-88.

21. Nicollet, C., et al., An innovative efficient oxygen electrode for SOFC: $\mathrm{Pr}$ 6011 infiltrated into Gd-doped ceria backbone, in International Journal of Hydrogen Energy. 2016, Elsevier Ltd. p. 15538-15544.

22. Shen, J., et al., Tuning layer-structured La0.6Sr 1.4MnO4+: $\delta$ into a promising electrode for intermediate-temperature symmetrical solid oxide fuel cells through surface modification, in Journal of Materials Chemistry A. 2016, Royal Society of Chemistry. p. 10641-10649.

23. Akbari, Z., A. Babaei, and A. Ataie, Effective enhancement of electrochemical properties of LSM oxygen electrode in SOCs by LNO nano-catalyst infiltration, in Journal of Ultrafine Grained and Nanostructured Materials. 2018. p. 53-59.

24. Ruiz-Trejo, E., A. Atkinson, and N.P. Brandon, Metallizing porous scaffolds as an alternative fabrication method for solid oxide fuel cell anodes, in Journal of Power Sources. 2015, Elsevier B.V. p. 81-89.

25. Lee, S. and K. Gerdes, Functional nanostructure engineering of SOFC cathode by solution infiltration, in ECS Electrochemistry Letters. 2015. p. F17-F20.

26. Huang, Y.L., A.M. Hussain, and E.D. Wachsman, Nanoscale cathode modification for high performance and stable low-temperature solid oxide fuel cells (SOFCs), in Nano Energy. 2018, Elsevier Ltd. p. 186-192.

27. Tullo, A.H. Is ammonia the fuel od the future. 2021 [cited 2021 7/5/2021]; Available from: https://cen.acs.org/business/petrochemicals/ammonia-fuel-future/99/i8. 